
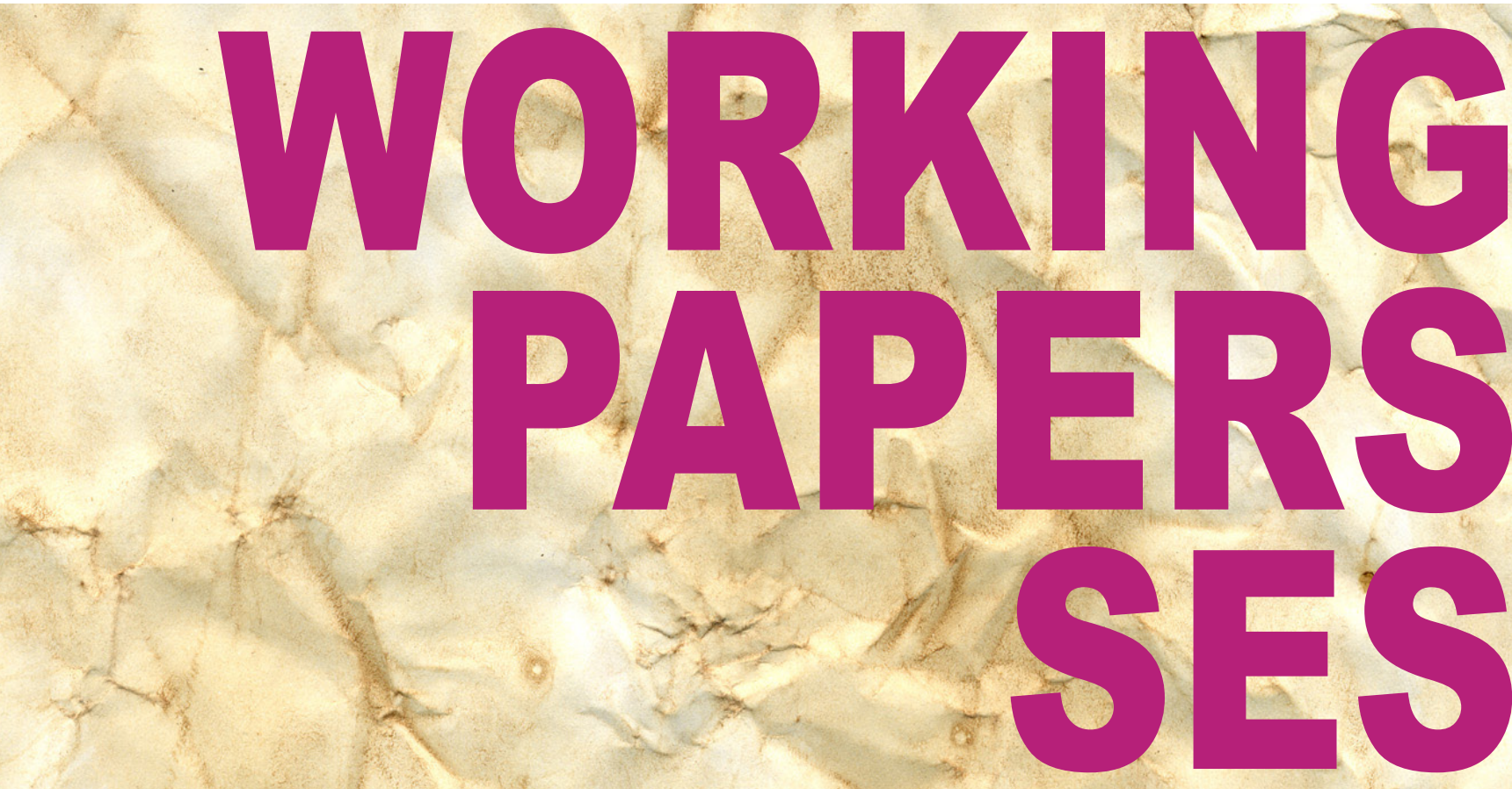

Multi-Brand Loyalty in

Consumer Markets:

A Qualitatively-Driven Mixed

Methods Approach

Ghizlane Arifine,

Reto Felix,

and

Olivier Furrer 


\title{
Multi-Brand Loyalty in Consumer Markets: \\ A Qualitatively-Driven Mixed Methods Approach
}

\author{
Ghizlane Arifine \\ University of Fribourg, Switzerland \\ e-mail: ghizlane.arifine@unifr.ch \\ Reto Felix \\ University of Texas Rio Grande Valley, USA \\ e-mail: reto.felix@utrgv.edu \\ Olivier Furrer \\ University of Fribourg, Switzerland \\ e-mail: olivier.furrer@unifr.ch
}

January 2019

Accepted for publication

European Journal of Marketing

\author{
Contact Author: \\ Olivier Furrer \\ Chair of Marketing \\ Department of Management \\ University of Fribourg \\ Bd de Pérolles 90 \\ 1700 Fribourg, Switzerland \\ e-mail: olivier.furrer@unifr.ch
}




\title{
Multi-Brand Loyalty in Consumer Markets: A Qualitatively-Driven Mixed Methods Approach
}

\begin{abstract}
Purpose-Although multi-brand loyalty (MBL) in consumer markets has been identified in previous brand loyalty research, empirical studies have not yet explored the facets of its different types. This article seeks a deeper understanding of MBL by investigating its different types and facets.
\end{abstract}

Design/methodology/approach—This study uses a sequential, qualitatively-driven mixed method design consisting of in-depth interviews and supplementary survey research.

Findings-The findings of this study suggest that mood congruence, identity enhancement, unavailability risk reduction and market competition are the most important facets that explains the two types of MBL (complementary-based and product substitutes). Furthermore, the findings show that the family factor can motivate consumers to be multi-brand loyal by adding brands to an initially family-endorsed brand.

Research limitations/implications - This study advances the conceptual foundations of MBL and extends previous research on brand loyalty. Some of the findings may be limited to the economic and cultural context of relatively affluent countries with an abundance of market offers.

Practical implications-Marketing managers gain insights into how to manage brand loyalty as well as how to transition from MBL to single-brand loyalty.

Originality/value - The study generates novel insights into the facets of different types of MBL.

Keywords: Multi-brand loyalty, relationship marketing, decision-making heuristics, mixed method design, grounded theory, thematic analysis

Paper type: Research paper 


\section{Introduction}

Achieving customer loyalty is a central goal for most firms (Ngobo, 2017; Watson et al., 2015) due to its contribution to their profitability (Reinartz et al., 2005) and long-term survival (Agustin and Singh, 2005). Relative to non-loyal customers, loyal customers engage more in positive word-of-mouth communication (Roy et al., 2014), are less price sensitive (Yoon and Tran, 2011) and resist competitive offers, even when they are objectively better (Ahluwalia, 2000). However, across various consumer markets, many customers appear to be loyal to more than just one brand (Uncles and Kwok, 2013), which runs counter to a firm's interests in fully exploiting the potential benefits of customer loyalty. As Quoquab et al. (2014) observe in the telecommunication industry, many users subscribe to multiple mobile phone service providers. Similarly, most households use two or more financial service providers (Ngobo, 2004), and a substantial number of smokers are loyal to more than one brand (Dawes, 2014). In the tourism industry, consumers are frequently loyal to more than just one tourist destination (AlmeidaSantana and Moreno-Gil, 2018) or service provider (McKercher et al., 2012).

The phenomenon of customers being loyal to more than one brand has been described in the literature using various terms, such as multi-brand loyalty (MBL) (Dick and Basu, 1994; Fournier and Yao, 1997; Jacoby, 1971; McMullan and Gilmore, 2008; Oliver, 1999;), divided loyalty (Uncles et al., 2003) and polygamous loyalty (Uncles and Kwok, 2013). Despite previous efforts to identify different types of MBL (Felix, 2014; Ramaswami and Arunachalam, 2016), little progress has been made in terms of developing a theoretically sound and empirically grounded framework that describes how MBL emerges. Research exploring the underlying facets of different MBL types is virtually non-existent, suggesting the need for a better understanding of MBL for both theoretical and managerial reasons. 
The present study seeks to contribute to the brand loyalty literature by filling this gap and by positioning our research at the confluence of three complementary streams of research: multibrand loyalty, affect and identity in brand loyalty, and risk and competition in brand loyalty. Figure 1 shows the position of previous research related to brand loyalty and illustrates the original positioning of our study in a neglected area. The current literature on single-brand loyalty has focused strongly on issues such as the relationship between customer satisfaction and brand loyalty (e.g., Dwivedi et al., 2018; Homburg and Giering, 2001; Kumar et al., 2013;

Oliver, 1999; Walsh et al., 2008). In addition, an important stream of research on brand loyalty is informed by a predominantly cognitive representation of decision making, such as risk and competition (e.g., Empen et al., 2015; Ngobo, 2017; Uncles et al., 2003; Walsh et al., 2007). Complementing the cognitive perspective on brand loyalty is another stream of loyalty research that relates to affect (i.e., moods and emotions) and consumer identity (e.g., Carroll and Ahuvia, 2006; Chaudhuri and Holbrook, 2001; Fournier and Yao, 1997; He et al., 1012, Huang et al., 2015; Sirgy et al., 2008). A presence of both cognitive and emotional aspects can be observed in some studies, such as Chaudhuri (1997) and Matzler et al. (2008).

As Figure 1 shows, the concept of MBL has received only limited attention in the literature. Some authors acknowledged the existence of MBL, but without making it the focus of their research (Dick and Basu, 1994; Leenheer et al., 2007; Uncles and Kwok, 2013; Oliver, 1999; Yi and Jeon, 2003). Among those studies that further investigate MBL (Almeida-Santana and Moreno-Gil, 2018; Dawes, 2014; Jacoby, 1971; McKerchner et al., 2012; Uncles et al., 2010; Xiong et al., 2014), very few (Felix, 2014; Quoquab et al., 2014; Ramaswani and Armachalam, 2016) combine insights from research on affect and identity, and risks and competition, respectively. To the best of our knowledge, no study has simultaneously combined insights from the three streams of research to enrich our understanding of multi-brand loyalty. Thus, the 
current literature on MBL remains fragmented and additional research is needed to integrate MBL research with other relevant research streams from marketing and consumer decision making.

Moreover, from a methodological point of view, most studies on MBL have adopted quantitative approaches (Almeida-Santana and Moreno-Gil, 2018; Dawes, 2014; Jacoby, 1971; Ramaswani and Armachalam, 2016; Uncles et al., 2010; Xiong et al., 2014), which are not particularly well suited to distinguish between different facets of MBL. Qualitative studies investigating MBL from a discovery-oriented perspective with the objective of providing a richer and more nuanced understanding of the phenomenon and its different facets (Felix, 2014; McKerchner et al., 2012; Quobab et al., 2014) are very sparse and remain limited in their scope. Despite the merits of both quantitative and qualitative MBL studies, there exists a need to overcome their respective limitations and reconcile their findings. Specifically, on the one hand, quantitative studies on MBL have, so far, not been successful with integrating the insights of the affect-focused perspective of consumer decision making which acknowledges that consumers are frequently driven by emotions and apparently irrational identity projects. On the other hand, the very few qualitative studies on MBL suffer from highly contextualized findings with potentially limited generalizability. To address this gap in the literature, the current study adopts a qualitatively-driven mixed methods approach (Leech and Onwuegbuzie, 2009) with a core component consisting of in-depth interviews, followed by a supplementary component based on survey research. This procedure allows us to present a nuanced and theoretically-grounded account of MBL as well as providing initial estimations regarding the transferability of our findings. That is, our mixed methods approach enhances credibility and integrity of the results, increases completeness through the analysis of both qualitative and quantitative data, and provides opportunities for triangulation and corroboration of the findings (Harrison and Reilly, 
2011). Thus, we follow McDonald's (2011) argument, which points out the advantages of mixed-methods designs by explaining that a mixed-methods approach serves "as a means of gaining both an in-depth understanding of the range of relevant attitudes and behaviours, and then to quantify the extent to which they are held or undertaken" (p. 783).

Consequently, the contribution of this research is twofold. First, the findings of current study advances brand loyalty theory by extending previous work on brand loyalty in a consumer context (Dick and Basu, 1994; McMullan and Gilmore, 2008; Oliver, 1999; Walsh et al., 2008) and specifically focusing on the meaning of MBL and addressing facets of two of its different types. More specifically, this research identifies mood congruence, identity enhancement, unavailability risk reduction and market competition as foundational facets of two types of MBL, perfect substitutes MBL (PS-MBL) and complements-based MBL (CB-MBL). Second, the results of the study illustrate how family influences can either promote or attenuate MBL through processes of adherence, expansion and rebellion. The insights gained provide marketing practitioners with suggestions on how to increase brand loyalty in increasingly competitive marketplaces, characterised by customers with more complex, sometimes ambivalent motivations and personality configurations. Overall, the findings address an important gap in the literature by integrating both cognitive and emotional accounts into our understanding of different types of MBL.

\section{Theoretical framework: From single- to multi-brand loyalty}

\section{Brand loyalty: Conceptualization and Definitions}

In the extant literature, brand loyalty appears as a two-dimensional construct that includes attitudes and behaviours (Brunner et al., 2008; Chaudhuri and Holbrook, 2001; Ngobo, 2017; Walsh et al., 2008; Watson et al., 2015). Keller (1993, p. 8) suggested that brand loyalty occurs 
"when favorable attitudes for a brand are manifested in repeat buying behavior", and Oliver (1999, p. 34) defined it as "a deeply held commitment to rebuy or repatronize a preferred product/service consistently in the future, thereby causing repetitive same-brand purchasing, despite situational influences and marketing efforts having the potential to cause switching behavior". The behavioural dimension of brand loyalty thus is based on purchase frequency and sequences. The measure of customer repeat purchase was used widely in previous studies because it captures obvious benefits for a firm's financial performance (Watson et al., 2015). The attitudinal dimension instead addresses factors associated with repurchase behaviour other than those derived from the situation (e.g., lack of viable alternatives, habit) (Dick and Basu, 1994; Watson et al., 2015). Dick and Basu (1994) suggested that this dimension distinguishes between "true loyalty" and "spurious loyalty". Specifically, behaviourally loyal customers who have consistent attitudes tend to stay loyal to the same brand, but behaviourally loyal customers who have inconsistent attitudes are more likely to switch to other brands. Similarly, RundleThiele and Bennett (2001) posited that without an understanding of attitude toward the brand, it would be difficult to design marketing programs to modify behavioural loyalty because they consider behavioural loyalty the observable outcome of attitudinal loyalty. It is indeed the decoupling between attitude and behaviour that distinguishes MBL from SBL.

\section{Risk and Competition in brand loyalty research}

Risk reduction has been acknowledged as one of the fundamental motives for brand loyalty (Mitchell and Boustani, 1993; Verhage et al., 1990). For example, Gounaris and Stathakopoulus (2004) found that risk-averse consumers show higher levels of both attitudinal and behavioural loyalty to a specific brand. Previous research suggested that brand loyalty works as a decision heuristics for risk-averse consumers because it builds trust (Mitchell, 1999). This notion is 
supported by a recent study showing that when perceived consumer risk is low, brand satisfaction alone is a strong predictor of brand loyalty, whereas when perceived risk is high, brand trust is a better determinant of brand loyalty (Paulssen et al., 2014). Importantly, the riskreducing effect of brand loyalty may be attenuated or even completely eroded when the target brand is not available at the point of purchase (Matzler et al., 2008). Further, competitor's actions have shown to influence brand loyalty. For example, Ngobo (2017) found that feature advertising, end-of-aisle product displays, and pricing influence how consumers transition between true loyalty, latent loyalty, and no-loyalty conditions. In support of the notion of loss leadership, recent research also suggested that companies target price promotions for sub-brands towards loyal consumer segments (Empen et al., 2015). These important streams of research lead to the question how risk and the availability of competing brands in the market are related to multi-brand loyalty.

\section{Affect and identity in brand loyalty research}

The important roles of affect and identity have been widely recognised in research on brand loyalty. Previous research demonstrated that positive affect in the form of emotional attachment relates positively to both attitudinal and behavioural loyalty (Chaudhuri and Holbrook, 2001). In some instances, the emotional attachment can be so strong that the extant literature has coined the notion of brand love (Batra et al., 2012; Carroll and Ahuvia, 2006). The positive relationship between emotional attachment and brand loyalty has been shown not only for branded products, but also in the context of human brands, such as famous artists and athletes (Huang et al., 2015). Further, previous research suggested that social identity and identification with the brand influences brand loyalty (He et al., 2012). For example, the positive effect of self-congruity with the brand on brand loyalty has been shown in different contexts, such as conventional consumer 
products or sponsorship events (Sirgy et al., 2008). In fact, consumers have been shown to be loyal to specific brands as part of their individual identity projects. For example, Fournier and Yao (1997) described how one of their informants, 23-year old Sara, develops loyalty to the Gevalia coffee brand to express taste and separate her from her frugal and conservative upbringing at a farmer family. Whereas the extant literature provides compelling evidence that affect and identity are important aspects of SBL, very little is known on how these factors relate to MBL.

\section{Multi-brand loyalty}

Multi-brand loyalty reflects a preferential, attitudinal and behavioural response to more than one brand in a product category (Jacoby, 1971; Oliver, 1999). Similar to SBL, MBL thus combines attitudinal and behavioural aspects (Dick and Basu, 1994; Felix, 2014; Oliver, 1999). Oliver (1999) asserted that the same conceptual logic that applies to SBL, including attitudinal and behavioural dimensions, should apply to MBL: a customer can prefer and express positive attitudes toward two or more brands over all others, and also simultaneously repurchase them. For the purpose of this study, we draw on the conceptualisation provided by Felix (2014) and define MBL as consistent and repetitive purchase of two or more brands, accompanied by high commitment and involvement, while ignoring any other brands. We further define the multibrand loyalty set as the set of brands that meet the criteria above.

Few researchers distinguished different types of MBL and their facets. For example, Felix (2014) identified three types of MBL: "perfect substitute loyalty", which occurs when customers perceive two or more brands in a given product category as virtually identical and divide their loyalty between them; "specialized loyalty", such that customers differentiate among brands and combine them to fulfil different needs or adapt their purchases to different contexts; and "biased 
loyalty", which develops when customers are loyal to several brands, but prefer one over the others. Similarly, drawing on customer value and brand equity theory, Ramaswami and Arunachalam (2016) proposed two explanations of MBL that align with Felix's first two types of MBL. The "equivalence explanation" suggests that customers develop high, similar levels of attitudinal loyalty to several brands when they perceive the firms' value propositions as similar, and the "comparative advantage explanation" posits that customers believe firms offer differential value propositions, whose combined value is similar. Notwithstanding the merits of these classifications, little progress has been made with regard to how specific facets of MBL emerge.

Furthermore, some authors have speculated about factors that might influence MBL (e.g., Dick and Basu, 1994; Jacoby, 1971), though without sufficient empirical grounding. Early conceptual studies argued that MBL occurs when customers cognitively organize brands in a given product category into acceptance, rejection and neutral categories. For example, Jacoby (1971) proposed that MBL may appear when customers select more than one brand in the acceptance region, and Dick and Basu (1994) suggested that strong attitudes toward two or more brands, coupled with little perceived differentiation, may lead to MBL because the alternatives are perceived as equally satisfying. Moreover, Walsh et al. (2007) noted some conditions, such as information overload or ambiguous product information that may motivate consumers to become less loyal to a single brand. When customers are multi-brand loyal, they may also benefit from the additional advantage of flexibility. In a study of loyalty programs, Xiong et al. (2014) found that customers choose to join multiple loyalty programs to gain more flexibility in accumulating their loyalty points. However, empirical evidence in support of these predictions is limited and little is known regarding the specific facets of different MBL types. Addressing this 
research gap, the current study seeks to provide a better understanding of different MBL types and facets, based on empirical evidence from the field.

\section{Methodology}

To address the scarcity and fragmented nature of current research on MBL, we used a mixedmethods design to gain an in-depth understanding of the phenomenon of interest and to quantify the extent to which related attitudes or behaviours occur (Coulter et al., 2003; McDonald, 2011). Our specific strategy employed a sequential, qualitatively-driven research approach (Leech and Onwuegbuzie, 2009) consisting of a core component of in-depth interviews, followed by a supplementary component based on survey research. Overall, we argue that the lack of empirical, in-depth research into the facets of MBL necessitates an interpretative, discovery-oriented approach to capture deep insights into customers' emotions and cognitive processes (Corbin and Strauss, 2008; Goulding, 1999). However, we follow Mason (2006) in her argument that supplementary quantitative studies not only serve to validate findings, but also open our perspective to the multi-dimensionality of lived experience. That is, the qualitative and quantitative phases in our research are used to expand on one another: On the one hand, the qualitative study allowed exploring MBL meanings and facets and informed scale items for the quantitative phase. On the other hand, the quantitative study provided credibility to the qualitative outcomes and enhanced the integrity of the findings (Harrison and Reilly, 2011).

\section{Interviews}

Following the procedure of grounded theory (Glaser, 1978), the qualitative part of this research builds on the three pillars of theoretical sampling, constant comparison and saturation (Goulding, 2002; Saunders et al., 2018). Theoretical sampling refers to the selection of informants based on 
developing categories and emerging theory (Coyle, 1997). Similar as in previous research (e.g., Homburg et al., 2017; Raggio et al., 2014), we implemented our sampling strategy through three stages, where findings from previous stages in the field research informed the topics and questions used in the subsequent stages. The first stage aimed at understanding the meaning of the MBL concept, identifying its relevance and importance in a consumer context and exploring its facets. Semi-structured interviews were appropriate as they offer the possibility to identify concepts, provide structure to the interview process while encouraging interviewees to freely discuss the phenomenon of interest in their own words and allowing the interviewer to probe thoughts as needed (Bernard, 1988). Stage 1 was conducted with 20 customers residing in Switzerland. Representing an affluent economy with annual purchasing power parity per capita of $\$ 80,560$ (World Bank, 2017), Switzerland is characterised by the presence of both local and global brands as well as a sophisticated retail infrastructure, indicating that it offers a suitable context for this study. Following established procedures for studies striving for conceptual depth rather than statistical generalizability (Epp and Price, 2010), informants were selected upon the basis of gender, age, job nature to ensure variance in the sample (Shum et al., 2008). Moreover, the selection process focused on participants who were responsible for most of the decisionmaking in their households and made the purchases in the focal product categories for this study. These pertinent product categories, for which the respondents were multi-brand loyal, emerged out of informal discussions with customers prior to the main study, which produced seven major product groups: non-alcoholic beverages, alcoholic beverages/cigarettes, dairy food products, snacks, personal care/cleaning items, cosmetics/beauty products and consumer durables. Out of the group of sampled informants, 50 per cent were female, and the average age was 33.9 years. Furthermore, 65 per cent were single and 35 per cent were married or in a relationship. The interviews lasted between 25 and 48 minutes (Appendix 1 - Panel A). 
The first part of the semi-structured interviews asked about informants' buying habits for 38 product categories. On the basis of the informants' self-reported buying behaviour, their purchases were classified into four initial loyalty categories (no loyalty, multi-brand loyalty, single-brand loyalty, or no purchase). We repeated this initial classification of buying habits for stages 2 and 3 of our research. Across all product categories, the three aggregated samples provided substantial occurrences of MBL in each category. Appendix 2 shows the frequencies for a total of 30 informants. A visual inspection of the data did not indicate any specific patterns (e.g., more MBL instances for hedonic versus utilitarian products). Next, the interviewers invited the informants to talk in more detail about the brands they buy in each category. All informants agreed to audiotape the interviews, which resulted in 164 pages of double-spaced, verbatim transcripts.

Based on responses to this initial exploratory phase, we selected topics that would be important to investigate in more details and conducted a second wave of open-ended, unstructured interviews (Fontana and Frey, 1998) to further advance our theoretical foundation. This second stage allowed us to ask additional clarifying questions based on prior responses and develop a deeper understanding of the MBL facets. Stage 2 of the qualitative study consisted of eight open-ended, unstructured interviews, which produced 82 pages of double-spaced, consumer-driven text. Four interviews were continuations with informants from the first stage, and the other four were with new informants (Appendix 1 - Panel B). Interviews lasted between 40 and 60 minutes. Of the four new informants, three were women, and the average age was 31.75 years. Two of the informants were single, and the other two were married or in a relationship.

Finally, Stage 3 of the qualitative study aimed at increasing trustworthiness regarding the emerging themes and to probe them in more depth. This stage (Appendix 1 - Panel C) included 
unstructured interviews from six additional informants. Four of the informants were female and the average age was 31.5 years. Two informants were single and four in a relationship or married. This part of the data collection process produced 84 pages of double-spaced transcripts. Interviews lasted between 59 to 70 minutes (Appendix1- Panel C). Data and theoretical saturation (Goulding, 2005; Saunders et al., 2018) were achieved because towards Stage 3 of the data collection process, information obtained from the informants became redundant, and the theoretical framework of four facets of MBL became more stable and robust.

To reduce biases, all interviews in the three stages were conducted by the same researcher (Corbin and Strauss, 2008). Informants were assured of confidentiality and no incentive was offered to informants for their participation. To enhance the voice of the informants, the procedure also involved member checks and invitations to informants to comment on the transcripts (Creswell and Miller, 2000). Member checks were initiated by the interviewer and feedback was analysed by the researcher team. For all three stages of the qualitative research phase, member checks produced very few comments from informants, resulting in minor rewording for some of the transcripts without changing their meaning.

\section{Analysis and coding}

Thematic analysis (Boyatzis, 1998) served to identify and report themes derived from the data. Following Epp and Price (2010), the analysis began with a holistic review of all transcripts, followed by open, axial and selective coding (Corbin and Strauss, 2008; Homburg et al., 2017). Two authors coded the transcripts independently, but also frequently compared their interpretations and insights to enhance reliability (Batonda and Perry, 2003). Open coding, consisting of a line-by-line analysis of words and sentences in the text, uncovered zero-order concepts across interviews (Miles and Huberman, 1994, Homburg et al., 2017) (Appendix 3). 
During axial coding, we contextualized the zero-order categories with supplementary literature, searched relationships among them and organized them into first-order themes (e.g., adaptation to mood state, Appendix 3). Finally, selective coding allowed us to further integrate the firstorder categories into second-order categories and develop the themes for the theoretical framework (Corbin and Strauss, 2008). We iterated frequently between data and theory to probe the patterns that materialized from the analysis (Närvänen and Goulding, 2016). Constant comparison, the comparison of each incident in the data with other incidents belonging to the same category and across categories (Spiggle, 1994), helped to explore similarities and differences (Goulding, 2002).

\section{Survey instrument and sample}

Once gaining an in-depth understanding of how MBL emerges, we conducted a quantitative study to assess the occurrence of MBL types and facets (McDonald, 2011). Following Brennan et al. (2003), we generated a list of items for each type and facet of MBL based on the topic guides used during the qualitative interviews and the informants' verbatim quotes. Next, we examined content validity by asking five experts (four senior academics and one practitioner) to indicate for each item whether it was (1) clearly representative, (2) somewhat representative or (3) not representative of the underlying construct (Brennan et al., 2003). The experts were further asked to provide additional comments whenever they judged an item to be not representative. Based on the experts' feedback, we deleted items deemed not representative by two or more experts and/or unclear by at least one expert. Thus, we retained only those items that were judged appropriate in regards to the corresponding construct (Delcourt et al., 2016). In addition, the final questionnaire with refined items was pretested prior to data collection with 30 
consumers from the same panel as the main sample. Because no changes in the questionnaire were needed, these 30 respondents were retained for the main sample.

Regarding the sample, a national Swiss sample was drawn from Qualtrics' online platform, one of the largest consumer panel providers in Europe. Previous research (Smith et al., 2016) suggests that the response quality of Qualtrics' consumer panels tends to be superior to those of Amazon's MTurk. Participants were selected randomly from the online panel and paid CHF 5.19 (approximately USD 5.21) for participation in the survey. In total, 629 panel members answered the survey online. Thirty-two questionnaires were incomplete and therefore discarded, resulting in 597 participants who completed the questionnaire (53.1 per cent female, mean age $=40.1$ years) with an average completion time of about 10 minutes. Participants were first asked if they could remember any product category for which they usually buy more than one brand. Out of the 597 respondents in total, 259 ( 54.1 percent female, mean age $=35$ years) responded yes to this question. Only participants who responded yes were considered as multibrand loyal and were asked to fill in the survey. They were then asked to indicate the product category (e.g., sport shoes) and the brands they buy most frequently (e.g., Nike, Adidas, Puma). Next, they were asked to indicate the degree of their agreement with a series of items related to types and facets of MBL informed by the qualitative phase of our research on seven-point Likert scales ( $1=$ totally disagree to $7=$ totally agree) (Appendix 3$)$. We removed 11 respondents who provided non-meaningful information for the product category question. Thus, the final sample consisted of 248 useable cases. This sample size is above the minimum sample size of $n=200$ recommended by Loehlin (1998) for confirmatory factor analysis and also above previous research using hierarchical cluster analysis (Ouwersloot and Odekerken-Schröder, 2008). 


\section{Findings from the main study}

\section{Types and facets of multi-brand loyalty}

Our analysis uncovers two main types of MBL: perfect substitutes (PS-MBL) and complementbased (CB-MBL). For PS-MBL, brands in the loyalty set are perfect substitutes, and customers see them as identical in their perceived value, image, and utility. For CB-MBL, customers perceive brands as complementary, meaning that the brands in the loyalty set offer identical perceived value overall but differ on specific product attributes. For example, Daniel regarded two chocolate brands, Cailler and Lindt, as complements, but Sophia perceived two brands, Vögele and Dosenbach, as similar brands in their product value and utility:

For chocolate, I prefer two brands. I buy the two brands for different reasons: the expensive one to offer it to my guests at home with a coffee, and the cheaper one for daily consumption, for my family and myself. [Daniel, first stage] I prefer two brands of shoes. Both brands have the same style, the same price level, it is Vögele and Dosenbach. I know if I go there, it is the same style of shoes, almost the same level of quality [...] I just choose these two brands because I know exactly what I can expect in terms of quality. [Sophia, second stage]

Moreover, four facets emerged from the data, which may help explain PS-MBL and CB-MBL: unavailability risk reduction, market competition, mood congruence, and identity enhancement (Figure 2). These four facets gain their own specific meaning in the context of MBL and are discussed below. 
Unavailability risk reduction. Previous studies identify brand loyalty as a dominant heuristic that consumers employ to reduce risk (Mitchell, 1999). Matzler et al. (2008) report that more riskaverse consumers exhibit higher levels of attitudinal and behavioural loyalty toward a brand, but if the preferred brand is temporarily unavailable, SBL might become an ineffective heuristic for simplifying the purchase decision because customers are forced to put more effort into searching for a new, similar alternative. As evidenced by explanations from several informants, some consumers choose MBL as a decision-making heuristic to reduce the brand unavailability risk inherent to SBL without losing the benefits of brand loyalty for reducing cognitive effort in the purchase decision. In other words, MBL increases the probability that at least one preferred brand is available at the point of purchase:

For example, for clothes, I want to spend as little time and effort as possible for shopping. My loyalty to few clothing brands is an advantage because I know I will find at least one of my preferred brands available, and I am not willing to look at other brands because two options for me are enough. Looking for new brands takes a lot of time. [Eric, second stage] For wine, taste is the important factor for me. I like several different companies for soft wine; I keep those alternatives to be sure to find one of them wherever I go. It is good to know a few brands in case I don't find the one I am looking for. [Christopher, first stage]

In this sense, MBL attenuates the risk of brand unavailability because, reiterating the words of the informants, "I know I will find at least one of my preferred brand available" (Eric, second stage), and "it is good to know a few brands in case I don't find the one I am looking for" (Christopher, first stage).

In a store loyalty context, evidence also indicates that MBL works as a risk reduction strategy if consumers shop at more than one store for the same product category. This situation 
occurs when consumers like two stores equally, and MBL on the store level trickles down to the product level. For example, Emma is loyal to both Migros and Coop, the two prominent retail stores in Switzerland. These two stores frequently have different brands for the same product category in their assortment. In this case, MBL allows consumers to maintain several options on the store level without the risk of failing to find their preferred product or brand:

The reasons I am loyal to two brands of shampoo is that I don't need to try other brands. Now, I want to have those two options because it depends really on the store I visit. Sometimes I go to Migros, but if I go to visit my parents, I go to Coop. So, it really depends on this. I have one brand in Migros, and one brand in Coop, and it gives me flexibility.

[Emma, second stage]

Market competition. In addition to reducing the brand unavailability risk, the benefits of free market economies encourage MBL. Market economies usually offer an abundance of product choices, not only when it comes to food (e.g., Marshall, 2005), but in virtually every product category. This context favours customers with a high variety-seeking propensity. Intense competition, coupled with products that consumers perceive as relatively homogenous, may encourage them to be non-loyal rather than loyal. As the testimonials from the informants suggest, the desire to expand consumption beyond a single brand can be driven by rational, economic considerations, such that consumers buy products with similar quality and price:

I think I am quite loyal to different brands in several product categories because I find there is quite a bit of selection in the market. And I tell myself, why not? Why stay with only one? If two or three brands have the same level of quality and price, why not? And as I said, I always have this tendency to challenge my preferred brands to see if I have made a good decision, or if there is a better one. [Melanie, third stage] 
In addition, hedonic motives appear in the informants' discourses, focused on experiences. This finding resonates with research that emphasises the importance of hedonic emotions for prompting a relationship between brand experience and brand loyalty (Ding and Tseng, 2015).

For food products, I always want to try different things, have new experiences and try new brands with different tastes since we are such a multicultural country. There are so many kinds of food; it is a good opportunity to try new things. [Daniel, second stage]

As the testimonial above shows, market competition may seduce consumers to try other market offers by insinuating that the variety of offers is just too good, too interesting or too exciting to miss. However, consumers with a low propensity to seek variety may not perceive this competition as an advantage and instead turn to MBL to mitigate the competitive pressures. Using MBL helps consumers reduce their cognitive effort, while still allowing them to choose from a brand set to avoid specific brand dependencies. The combined impact of competition and commoditization creates parity perceptions among two or more brands, which results in divided loyalty (Dick and Basu 1994; Uncles et al., 2003).

For food, I think I am in the middle. I don't like too much variety, and not too much being locked into one brand [...]. In Migros, for example, there are too many choices, and I feel lost. So, I go to Coop to buy most of the products I need, and I have my references there. [Christopher, second stage]

As the example above shows, MBL seems to serve for some consumers as an ideal middle point that combines the advantage of some variety with the simplified decision heuristics of SBL. Finally, the analysis reveals an interesting tension between opposing market forces. On the one hand, competitive markets seek to lure consumers away from a single brand (Menon and 
Kahn, 1995). On the other hand, companies strive to keep consumers loyal to their own single brand. Yet to stay competitive, they must offer more choices, which might drive consumers toward no-loyalty or MBL, depending on their variety-seeking propensity.

Mood congruence. Mood is a type of affect that, compared with emotion, tends to be longer lasting, lower in intensity and unrelated to a specific object or event (Bagozzi et al., 1999). As previous research shows, mood influences product evaluations, consumer preferences and behaviours (Forgas and Ciarrochi, 2001). The interview data also suggest that consumers use MBL, either consciously or unconsciously, as an instrument to align their consumption with their mood states. For example, Peter's chocolate consumption depends on his mood:

For chocolate, I have specific brands that I buy: Cailler, Villars, Lindt and Ragusa. If any of these brands [are] available, I don't buy another brand. Now if several of them are available or all of them, I buy the one I feel I want to eat [...] To offer to friends, I buy only two of them, and for myself it is more depending on my mood. I wouldn't be able to say exactly which mood for which chocolate, but I have the impression [that] I eat more milk chocolate during autumn and spring, and dark chocolate in summer, I don't know why. [Peter, second stage]

I like flavoured beer, like with strawberries for example. So, I know I will buy specific brands, which have this kind of beer. I also like one local brand. I like to have different brands in my fridge for myself and to offer to friends, and I choose one of them according to my mood, when I feel like drinking a beer. [Olivia, second stage]

As these examples show, MBL provides consumers with an opportunity to use the decision-making heuristics inherent in brand loyalty while allowing them to adjust their consumption to different mood states. Mood congruency theory thus might provide a framework 
to explain the underlying mechanism. This theory posits that consumers seek congruence between their mood state and their consumption-related behaviours (Maier et al., 2012). Consumers adjust their consumption to specific mood states, such as a "spring" or a "summer" mood (see Parker and Tavassoli, 2000, for an overview on how consumers adjust consumption to seasonal changes).

Identity enhancement. Identity refers to facets of the self that enable consumers to express who they are (Bhattacharjee et al., 2014). Through consumption practices and the use of material and symbolic resources, consumers define, shape and communicate their identities (Ulver and Ostberg, 2014). In a postmodern society, consumers may increasingly construct a fragmented sense of self, which can be ambivalent, contradictory and conflicting (Fírat et al., 1995). These consumers accordingly use MBL to combine the effort-reducing heuristic of brand loyalty with the playful opportunities of constructing multiple identities:

For colognes, I am loyal to two brands. I received them the first time as gifts, I tried them and I was satisfied. However, I switch between those two; one of them reflects for me maturity, the other one is more fun and young spirit [...] In fact, it gives me the opportunity to have different self-images. So, simply the way I want to be on Monday morning is not the same I want to appear on Saturday evening [laugh]. Monday morning, I attend a class, I want to look serious. For colognes, specifically, for me every cologne smells different. I assign to every one of my colognes specific elements. One of them, "Terre d'Hermes", is the cologne of the responsible and wise guy, I use it obviously Monday morning. The second one, "La Nuit de L’Homme”, I use Saturday evening to go out. [Philip, second stage]

Thus, MBL enables consumers to enact predefined personalities and assume different roles 
without losing the convenience of reducing their cognitive effort through the decision-making heuristic of brand loyalty. For Philip, being loyal to two different brands of colognes constitutes a means to enact two different selves, a mature and responsible one during the week and a more exciting, adventurous, young one on weekends. The accounts from informants thus partially overlap with perspectives on the weekend warrior and the ambivalent consumer. For example, Cova and Cova (2002) identify a segment of customers who enjoy experiencing a distinct car brand on weekends, to break free from the stressful workweek and share the experience of driving a special car. This experience enables them to enact different identity representations during the weekend compared with working days.

\section{Family influences}

The interviews also reveal that family reference group influences, such as traditions, practices and habits (Childers and Rao, 1992), shape brand loyalty through three mechanisms that can foster either SBL or MBL (Figure 3). The first mechanism reflects the positive influence of family members, such that consumers emulate and internalise brand attitudes and preferences from their parents, siblings or significant others (Pimentel and Reynolds, 2004). These positive influences typically lead to higher levels of attachment, endorsing SBL. For example, Claudia describes how the Mark \& Spenser tea brand reconnects her to her home and family in the U.K:

From 14 to 30 years old, I lived in the U.K., so, I think this culture is influencing my loyalty to brands. There is also an important point, for example the brands that I am loyal to, for example Mark \& Spencer's tea, it is because they remind me of home. So, it is a kind of homesickness - if I ever have that feeling, I have brands in my home, which connect me to the U.K. and to my family. [Claudia, third stage] 
Claudia's narrative describes a process of adherence to family values and preferences, which leads to SBL toward a family endorsed brand. Two other outcomes, rebellion and expansion (see Figure 3), move consumers in the opposite direction. Rebellion develops when people perceive brands endorsed by their family as representative of patronising behaviours that restrict their freedom. This theme is prevalent in adolescent consumers who select brands and products that give them a sense of independence and freedom from their parents' influence over their consumption decisions (Noble et al., 2009). Once they achieve the freedom to make their own decisions and develop real agency, these young consumers frequently abandon the familyendorsed brand as a means to break with the restraints imposed by family conventions, as evidenced in the excerpt below. Typically, rebellion generates SBL for an alternative brand. My parents worked their whole life for Nestlé, and as you know there are different brands that belong to Nestlé, like Nespresso, Nescafé, some brands of chocolate, and all of these brands are in my blood [laugh], and I never consume brands from competitors. You know, the only time I ever have eaten a competitor's brand of Nestlé was when I was a kid, and it was a "Kinder Surprise" chocolate, not more than 3 or 4 times, and that's it, because I was not allowed to. Now I buy another brand because I am an adult and I don't live with my parents anymore. [Philip, second stage]

Expansion describes a process by which consumers add to the family-endorsed brand rather than substituting for it. For example, Jennifer adhered to one brand of chips that was endorsed by her family and gained symbolic meaning because of its link to family camping trips, but she later added a second brand to her choice set because it represented her boyfriend's favourite brand. This process of expansion commonly results in MBL. 
For potato chips for example, I am loyal to two brands. For the first brand, since I was a kid, we went camping, and we had this small package in our bags. I liked the advertising on TV so much at this time, so, I keep buying it because it reminds me of my childhood. The second one, I just like it because my boyfriend likes it, and it gives me a reason to change from time to time, but still my favourite one is the first brand. [Jennifer, first stage]

\section{--- Insert Figure 3 Approximately Here ---}

\section{Survey findings}

As the survey items were developed specifically for this study and based on the qualitative study, we first used exploratory factor analysis (EFA) to assess the dimensionality of the scales (McDonald, 2011). Factor loadings from EFA were substantial and all items loaded on their respective constructs (Appendix 4). Thus, we continued to investigate the psychometric properties of the scales by running a confirmatory factor analysis (CFA) with IBM SPSS AMOS 25.0. The overall fit of the model was good $\left(\chi^{2}=215.97\right.$, d.f. $=108, \chi^{2} /$ d.f. $=2.00$, RMSEA $=$ .064 [90 per cent CI: .051; .076], SRMR $=.086, \mathrm{TLI}=.94, \mathrm{CFI}=.95$ ). Further, the psychometric properties of the scales based on factor loadings from CFA, Cronbach's alpha, average variance extracted (AVE) and composite reliability (CR) were satisfying (Appendix 4). To test for discriminant validity, we used the Fornell and Larcker (1981) criterion. Squared AVE values for each construct exceeded the inter-construct correlations between it and any other construct included in the model, with only one exception between mood congruence and market completion with a correlation which is slightly above the square root of the AVE of market competition (Appendix 5). Nevertheless, we can consider that discriminant validity was overall satisfactory. Appendix 5 also shows that the occurrence of biased MBL was only slightly 
correlated to the four facets of MBL, which is consistent with our findings from the qualitative part of this research where biased MBL did not emerge as a distinctive facet of MBL. In summary, the results from confirmatory factor analysis converge with the findings from the qualitative study and provide initial evidence that the four facets are valid representations of consumers' tendency to be multi-brand loyal.

Following the objectives and procedures of previous mixed-methods research (McDonald, 2011), the quantitative part of our research assessed the occurrence of the different MBL facets rather than testing causal relationships. The extant literature has suggested that cluster analysis is appropriate to achieve this objective. For example, Zarantonello and Schmitt (2010) used cluster analysis to assess the occurrence of four different experiential appeals (sensory, affective, intellectual, and behavioural). To explore whether consumers can be profiled based on the MBL facets we identified, we ran a hierarchical cluster analysis in IBM SPSS Statistics 25.0. Regarding the clustering algorithm, we used Ward's method, which is one of the most common measures of similarity (compare, e.g., Ouwersloot and Odekerken-Schröder, 2008). Based on the inspection of dendrograms, agglomeration schedules and centroid distances, we chose a threecluster solution as the most appropriate one because it was able to produce distinguishable consumer segments while keeping the number of clusters at a reasonable level for marketing managers.

--- Insert Table 1 Approximately Here ---

Next, we analysed the means for each cluster on each of the four MBL facets as well as for the occurrence of biased preferences, CB-MBL, and PS-MBL (Table 1). Cluster 1 includes respondents with high scores on unavailability risk reduction and market competition, a 
somewhat lower score on mood congruence, and a comparably low score on identity enhancement. The high score of 4.69 on market competition suggests that taking advantage of the variety of market offers seems to be an important aspect of MBL for Cluster 1. Cluster 2 (the largest segment) shows high scores on all four MBL facets. Importantly, Cluster 2 is differentiated from the other two clusters by a substantially higher score (4.08) on identity enhancement. Finally, Cluster 3 scores lower on all four MBL facets. However, the somewhat higher score on unavailability risk reduction suggests that this segment uses MBL predominantly as a strategy to safeguard against the risk of not finding their favourite brand in the store. Overall, these results suggest that the MBL facets identified in this research are able to differentiate between consumer segments.

Following the procedure recommended by Hair et al. (2010), we validated the cluster solution by splitting the sample randomly into two groups and ran separate cluster analyses on both samples. A comparison of the two resulting cluster solutions revealed in both cases a relatively small segment with high scores on all four MBL facets (Cluster 1), a relatively large segment with moderate scores on the four MBL facets, and a mid-sized segment with very low scores on the four MBL facets (Appendix 6). For both sub-samples, the identity enhancement score for Cluster 3 is particularly low, indicating that identity enhancement is not a relevant facet of MBL for this segment. Further, the overall means for the four MBL facets (in bold font) are very similar for both sub-samples, further adding to the robustness of the cluster solution.

\section{Discussion and implications}

Understanding multi-brand loyalty is important because consumers who choose among a set of several preferred brands (as opposed to being loyal to just one brand) jeopardize firms' ability to fully exploit consumer-firm relationships. Despite the agreement that MBL occurs in a wide 
variety of industries (Almeida-Santana and Moreno-Gil, 2018; McKercher et al., 2012; Ngobo, 2004; Quoquab et al., 2014), very little is known about how MBL emerges and to what extent different facets of MBL may differentiate between different consumer segments. Using a mixed methods approach (Harrison and Reilly, 2011; Leech and Onwuegbuzie, 2009), the current study first explores types and facets of MBL based on 34 semi-structured and in-depth interviews with 30 consumers in Switzerland, an advanced economy with a sophisticated retail infrastructure. This discovery-oriented part of the research is then complemented by a quantitative component which investigates the occurrence of the MBL facets identified in the qualitative phase of the study and provides initial evidence that the MBL facets are able to differentiate between different consumer segments. Our study extends previous research on single-brand and multi-brand loyalty and thus contributes to this literature in important ways. In the section that follows, we contrast the different facets of MBL which stem from our study with the extant literature on risk, market competition, affect, and identity in an SBL context. Table 2 shows how the extant literature has conceptualized conventional brand loyalty (i.e., SBL), and how these conceptualizations change their meaning in the context of MBL.

--- Insert Table 2 Approximately Here ---

Risk. The extant literature has conceptualized brand loyalty predominantly as a riskreducing strategy (Matzler et al., 2008; Mitchell and Boustani, 1993; Verhage et al., 1990). In simple terms, being loyal to a specific brand reduces the risk for the consumer to buy a product or service that is of low quality or does not meet expectations. Perceived risk plays a fundamental role when firms try to stimulate non-purchasers of a brand to purchase for the first time or to stimulate existing purchasers to purchase more (Mitchell and Boustani, 1993). 
However, our study finds that ironically, the risk-reducing strategy of brand loyalty actually generates a different type of risk - the possibility that the target brand is not available at the point-of-purchase. That is, the reliance on just one brand may backfire in cases when the brand is not available. Our findings show that some consumers use MBL strategically to hedge against this unavailability risk while still enjoying the benefits of loyalty (i.e., a reduction in cognitive effort in the decision making process). For example, a consumer loyal to two brands of beer can simply revert to the second brand in her loyalty set in case the first brand is not available. The findings from our quantitative study show that this risk reduction facet of MBL is specifically important for Segment 1 in our sample of Swiss consumers, but has also some significance for Segments 2 and 3 (Table 1). It is thus critical to differentiate the risk-reduction role of brand loyalty between SBL and MBL consumers.

Competition. One of the fundamental tenets of free market economies is competition. To succeed in a highly competitive market landscape, firms employ promotions such as feature advertising, end-of-aisle product displays and discounts to lure customers away from the competitor brand (Empen et al., 2015; Menon and Kahn, 1995; Ngobo, 2017). Firms able to develop trust and real relationships with customers achieve true brand loyalty, which makes them more resilient towards competitors' intents to stimulate brand switching. However, our research shows that whereas firms are trying to generate SBL, free markets with their high level of competition may play against them. That is, for some consumers, the plethora of market offers in advanced market economies is just too seducing to make them stick to only one brand. Therefore, they prefer to take advantage of competitive market structures while adopting simplified decision making heuristics from their loyalty to a small number of preferred brands. The results from the quantitative part of our research show that the availability of many attractive market offers facilitated by competitive markets is an important facet of MBL for Segments 1 
and 2 of our sample. It is therefore important to envision that marketing actions designed to foster SBL may have the opposite effect of leading to MBL when they are targeted towards the wrong customers.

Affect. Previous brand loyalty research has considered affect (i.e., emotions or moods) in the form of emotional attachment towards the brand. In general, those brands with higher emotional attachment attain more brand loyalty (Carroll and Ahuvia, 2006; Chaudhuri and Holbrook, 2001; Batra et al., 2012). Although we acknowledge that this perspective is important and holds also in a multi-brand loyalty context, our findings add a previously neglected aspect of affect to MBL research. Specifically, we find that emotional attachment does not guarantee unconditional loyalty because consumers in MBL frequently use different brands strategically to adjust to different mood states. For example, consumers may have a very high level of attachment to both Brand A and Brand B when it comes to chocolate, but they consume these different brands based on their mood states. Thus, mood congruence theory (Maier et al., 2005) explains why brands may receive quite diverging purchase volumes. For example, one of our informants from the qualitative phase of our research (Peter, second stage) indicated that his chocolate consumption depends on his mood, and that he eats more milk chocolate during autumn and spring, and dark chocolate in the summer. In an extreme case (which is indeed constructed and only serves for illustration), one might speculate that external factors such as an unusually warm and sunny autumn might shift chocolate consumption from Brand A to Brand B due to consumers' mood management. The results from our quantitative study suggest that mood congruence is an important facet of MBL, especially for Segment 2 (which is the largest segment with 51.21 percent of the respondents from our sample).

Identity. When it comes to issues of identity and identification, the extant literature on SBL has usually focused on the congruence between the brand and the self (He et al., 2012; 
Sirgy et al., 2008). Brands are used to build, reinforce, or express identity, or even for constructing whole identity projects (Fournier and Yao, 1997). These identity projects are goaloriented and logically assume one identifiable and distinguishable desired identity, such as a successful businesswoman or a happy family man (compare Arsel and Thompson [2011] for a discussion on how brands relate to consumers' identity projects). However, our findings suggest that identities can be diffuse and in some cases highly ambivalent. Some consumers reject the predictability of single identities and take advantage of the playful opportunities that arise from constructing multiple identities. MBL then becomes the heuristics that allows consumers enhance multiple identities with the effort-reducing heuristic of brand loyalty. The results from our quantitative study suggest that identity enhancement is able to differentiate between different consumer segments: Whereas identity enhancement was high for Segment 2, it was low for Segments 1 and 3. Thus, whereas for SBL consumers, brands may be purchased to fit with their identity, for some MBL consumers, several brands might be purchased instead to build up multiple identities.

Family influence. A fifth aspect of MBL that emerged from our qualitative interviews was the influence of family members. However, we felt that family influence is such a highly complex and multi-dimensional concept that it would have been beyond the scope of this paper to operationalize the measurement of family influence in the quantitative part of our study. Nevertheless, the verbatims from the interviews provide important insights regarding how family influence relates to MBL. Our findings distinguish three different manifestations of family influence, adherence, rebellion, and expansion (see Figure 3). Importantly for our research, family influence may not only strengthen consumer attachment to a brand (adherence) or shift attachment from one brand to another in an act to liberate oneself from family restraints (rebellion), but also add additional brands to the loyalty set, e.g., when a boyfriend/girlfriend or 
husband/wife introduce new brands to the partner, which are subsequently accepted without giving up the old brand (expansion).

In addition to this theoretical contribution, the findings of our study provide important implications for marketing practitioners. Because customer loyalty is split among different brands, firms typically regard MBL as a barrier to the full exploitation of the advantages of brand loyalty (Felix, 2014). That is, firms prefer to have customers that are 100 percent loyal rather than share sales with competitors' brands. To consolidate their customer loyalty, marketers thus may try to reduce the occurrences of each type of MBL. In order to address different types and facets of MBL, marketers will need to identify distinguishable segments of MBL customers for their specific markets, as exemplified in the quantitative part of our research. Because firms typically do not have prior knowledge about information related to the facets of MBL, marketers are advised to conduct market research as a first step to gain knowledge about the prevalence of different MBL facets for the market segments they target. Once firms have obtained this information, they can address specific facets of MBL as follows:

First, as shown in both the qualitative and quantitative sections of this study, customers adopt MBL to align their consumption to their mood state and identity projects, which may be particularly pertinent when brands fail to offer all the alternatives desired by consumers to match their different mood states or identity projects. Thus, marketers may choose to offer broader product lines to cover different mood states and consumer identities. However, marketing managers should use this strategy with caution because expanding the product line too broadly may expose the company to the risk of developing a brand personality that is perceived as schizophrenic (Gould, 2010). Perhaps the best solution would be to develop sufficiently differentiated and distinguishable sub-brands under a common umbrella brand or unified ownership. 
Second, our findings suggest that customers may be loyal to several brands to ensure product/brand availability at the retailer. This situation might be more prevalent when the firm suffers logistical problems in its distribution channels. To address this issue, firms could focus on adequate distribution strategies to guarantee regular stock at the point of sale. Brand availability in stores is important in this situation because customers may not go to the next store to buy the brand they prefer, but rather switch to the next-best option in their choice set. Furthermore, in a competitive environment, customers often perceive different products as similar in value, and they encounter several alternatives (Walsh et al., 2007). Therefore, firms may need to establish brand differentiation and a unique value proposition in terms of quality, design, performance or price. However, as a potential caveat, this strategy might not be effective for customers who exhibit high levels of variety seeking tendencies. Woratschek and Horbel (2006) highlight drawbacks associated with providing high product or service quality to variety seekers, in that these customers usually choose another brand for their next purchase even when they are satisfied and developed favourable attitudes toward an initial brand. Firms interested in converting multi-brand loyal into single-brand loyal customers may benefit from focusing on those customers who express little or even no interest in variety.

Third, this study invites managers to reflect on ways to manage family influences. For example, firms may strive to build relationship marketing strategies that emphasise existing family ties, tradition and heritage as a way to bind the next generation of customers to their brand and avoid their development into multi-brand loyal shoppers. Our findings reveal that consumers may be motivated to engage in expansion or rebellion, where customers either expand their brand repertoire or even actively rebel against prevailing family values through boycotting the original, family-endorsed brand. Thus, marketing managers could try to build on the process of adherence to counteract motives to expand or rebel. The opportunities for building brand equity 
and SBL through the influence of family values have been demonstrated in the extant literature (e.g., Bravo Gil et al., 2007), and Moore's et al. (2002) analysis of iconic brands that "run in families" provides insightful examples on how to execute such a strategy.

\section{Limitations and avenues for future research}

The current study also presents several limitations, which indicate potentially fruitful avenues for future research. Our research was situated in Switzerland, an affluent economy with a vast offer of local and global brands and a sophisticated retail infrastructure. The findings may be transferable to similar, Western-style, open markets; however, they are not necessarily as applicable to less competitive markets in developing economies with limited choices of products and brands. Further research could extend the findings from this study to different markets in emerging and less developed economies (Burgess and Steenkamp, 2006). Second, this research focuses on fast moving consumer goods and a limited number of consumer durables, such as clothing, watches and cell phones. Continued research might investigate the facets of MBL in relation to other durables with longer product lifecycles as well as services. Further, the quantitative part largely neglects how the different facets might interact and either amplify or attenuate the propensity of consumers to become multi-brand loyal. Fedorikhin and Cole (2004) cite an interaction effect between mood and perceived risk on product evaluations. Additional research could investigate the potential interaction effects of MBL facets in a quantitative research setting with additional samples. Concluding, despite the limitations outlined above, the current research provides novel insights into how MBL occurs and offers a theoretical foundation for future research in the area of brand loyalty. 


\section{References}

Agustin, C. and Singh, J. (2005), "Curvilinear effects of consumer loyalty determinants in relational exchanges", Journal of Marketing Research, Vol. 42 No. 1, pp. 96-108.

Ahluwalia, R. (2000), "Examination of psychological processes underlying resistance to persuasion”, Journal of Consumer Research, Vol. 27 No. 2, pp. 217-232.

Almeida-Santana, A. and Moreno-Gil, S. (2018), "Understanding tourism loyalty: horizontal vs. destination loyalty", Tourism Management, Vol. 65, pp. 245-255.

Arsel, Z. and Thompson, C.J. (2011), "Demythologizing consumption practices: how consumers protect their field-dependent identity investments from devaluing marketplace myths", Journal of Consumer Research, Vol. 27 No. 5, pp. 791-806.

Batonda, G. and Perry, C. (2003), “Approaches to relationship development processes in interfirm networks”, European Journal of Marketing, Vol. 37 No. 10, pp. 1457-1484.

Bagozzi, R.P., Gopinath, M. and Nyer, P.U. (1999), “The role of emotions in marketing”, Journal of the Academy of Marketing Science, Vol. 27 No. 2, pp. 184-206.

Batra, R., Ahuvia, A. and Bagozzi, R. (2012), “Brand Love,” Journal of Marketing, Vol. 76 No. 2, pp. 1-16.

Bernard, H.R. (1988). Research Methods in Cultural Anthropology, London: Sage.

Bhattacharjee, A., Berger, J. and Menon, G. (2014), "When identity marketing backfires: consumer agency in identity expression", Journal of Consumer Research, Vol. 41 No. 2, pp. 294-309.

Boyatzis, R.E. (1998), Transforming Qualitative Information: Thematic Analysis and Code Development, Sage Publications, Thousand Oaks, CA.

Bravo Gil, R., Fraj Andrés, E. and Martínez Salinas, E. (2007), "Family as a source of consumerbased brand equity", Journal of Product \& Brand Management, Vol. 16 No. 3, pp. 188-199. 
Brennan, D.R., Turnbull, P.W. and Wilson, D.T. (2003), "Dyadic adaptation in business-tobusiness markets", European Journal of Marketing, Vol. 37 No. 11/12, pp. 1636-1665.

Brunner, T.A., Stöcklin, M., and Opwis, K. (2008), "Satisfaction, image and loyalty: new versus experienced customers", European Journal of Marketing, Vol. 42 No. 9/10, pp. 1095-1105.

Burgess, S.M. and Steenkamp, J.B.E.M. (2006), "Marketing renaissance: How research in emerging markets advances marketing science and practice", International Journal of Research in Marketing, Vol. 23 No. 4, pp. 337-356.

Carroll, B.A. and Ahuvia, A.C. (2006), "Some antecedents and outcomes of brand love", Marketing Letters, Vol. 17 No. 2, pp. 79-89.

Chaudhuri, A. (1997), "Consumption emotion and perceived risk: a macro-analytic approach", Journal of Business Research, Vol. 39 No. 2, pp. 81-92.

Chaudhuri, A. and Holbrook, M.B. (2001), "The chain of effects from brand trust and brand affect to brand performance: the role of brand loyalty", Journal of Marketing, Vol. 65 No. 2, pp. 81-93.

Childers, T.L. and Rao, A.R. (1992), "The influence of familial and peer-based reference groups on consumer decisions”, Journal of Consumer Research, Vol. 19 No. 2, pp. 198-211.

Corbin, J. and Strauss, A. (2008), Basics of Qualitative Research: Techniques and Procedures for Developing Grounded Theory, Thousand Oaks, CA: Sage.

Coulter, R.A., Price, L.L. and Feick, L. (2003), "Rethinking the origins of involvement and brand commitment: insights from postsocialist Central Europe", Journal of Consumer Research, Vol. 30 No. 2, pp. 151-169.

Cova, B. and Cova, V. (2002), "Tribal marketing: the tribalisation of society and its impact on the conduct of marketing”, European Journal of Marketing, Vol. 36 No. 5/6, pp. 595-620. 
Creswell, J.W. and Miller, D.L. (2000), “Determining validity in qualitative inquiry”, Theory Into Practice, Vol. 39 No. 3, pp. 124-130.

Dawes, J. (2014), “Cigarette brand loyalty and purchase patterns: an examination using US consumer panel data”, Journal of Business Research, Vol. 67 No. 9, pp. 1933-1943.

Delcourt, C., Gremler, D.D., Van Riel, A.C.R. and Van Birgelen, M.J.H. (2016), “Employee emotional competence construct conceptualization and validation of a customer-based measure", Journal of Service Research, Vol. 19 No. 1, pp. 72-87.

Dick, A.S. and Basu, K. (1994), “Customer loyalty: toward an integrated conceptual framework", Journal of the Academy of Marketing Science, Vol. 22 No. 2, pp. 99-113.

Ding, C.G., and Tseng, T.H. (2015), “On the relationships among brand experience, hedonic emotions, and brand equity”, European Journal of Marketing, Vol. 49 No. 7/8, pp. 994-1015.

Dwivedi, A., Johnson, L.W., Wilkie, D.C. and De Araujo-Gil, L., (2018), “Consumer emotional brand attachment with social media brands and social media brand equity", European Journal of Marketing (forthcoming). doi: 10.1108/EJM-09-2016-0511.

Empen, J., Loy, J.-P. and Weiss, C., (2015), "Price promotions and brand loyalty: empirical evidence for the German ready-to-eat cereal market", European Journal of Marketing, Vol. 49 No. 5/6, pp.736-775.

Epp, A.M. and Price, L. (2010), “The storied life of singularized objects: forces of agency and network transformation”, Journal of Consumer Research, Vol. 36 No. 5, pp. 820-837.

Fedorikhin, A. and Cole, C.A. (2004), "Mood effects on attitudes, perceived risk and choice: moderators and mediators", Journal of Consumer Psychology, Vol. 14 No. 1/2, pp. 2-12. Felix, R. (2014), "Multi-brand loyalty: when one brand is not enough", Qualitative Market Research: An International Journal, Vol. 17 No. 4, pp. 464-480. 
Fírat, A.F., Dholakia, N. and Venkatesh, A. (1995), "Marketing in a postmodern world", European Journal of Marketing, Vol. 29 No. 1, pp. 40-56.

Fontana, A. and Frey, J.H. (1998), "Interviewing: The art of science”, in Denzin, N.K. and Lincoln, Y.S. (Eds.), Collecting and Interpreting Qualitative Materials, Sage Publications, Thousand Oaks, CA, pp. 47-78.

Forgas, J.P. and Ciarrochi, J. (2001), "On being happy and possessive: the interactive effects of mood and personality on consumer judgments", Psychology \& Marketing, Vol. 18 No. 3, pp. 239-260.

Fornell, C. and Larcker, D.F. (1981), "Evaluating structural equation models with unobservable variables and measurement error", Journal of Marketing Research, Vol. 18 No. 1, pp. 39-50.

Fournier, S. and Yao, J.L. (1997), "Reviving brand loyalty: a reconceptualization within the framework of consumer-brand relationships", International Journal of Research in Marketing, Vol. 14 No. 5, pp. 451-472.

Glaser, G. (1978), Theoretical Sensitivity, The Sociology Press, Mill Valley, CA.

Gould, S.J. (2010), "To thine own self(ves) be true: reflexive insights for etic self theory from consumers' emic constructions of the self", Consumption Markets \& Culture, Vol. 13 No. 2, pp. 181-219.

Goulding, C. (1999), “Consumer research, interpretive paradigms and methodological ambiguities”, European Journal of Marketing, Vol. 33 No. 9/10 pp. 859-873.

Goulding, C. (2002), Grounded Theory: A Practical Guide for Management, Business and Market Researchers, Sage, London.

Goulding, C. (2005), "Grounded theory, ethnography and phenomenology: a comparative analysis of three qualitative strategies for marketing research", European Journal of Marketing, Vol. 39 No. 3/4, pp. 294-308. 
Gounaris, S. and Stathakopoulus, V. (2004), "Antecedents and consequences of brand loyalty: an empirical study", Journal of Brand Management, Vol. 11 No. 4, pp. 283-306.

Hair, J.F., Black, W.C., Babin, B.J. and Anderson, R.E. (2010), Multivariate Data Analysis (7 $7^{\text {th }}$ ed.), Upper Saddle River, NJ: Prentice-Hall.

Harrison, R.L. and Reilly, T.M. (2011), "Mixed methods designs in marketing research", Qualitative Market Research: An International Journal, Vol. 14 No. 1, pp. 7-26.

He, H., Li, Y. and Harris, L. (2012) "Social identity perspective on brand loyalty", Journal of Business Research, Vol. 65 No. 5, pp. 648-657.

Homburg, C. and Giering, A. (2001), "Personal characteristics as moderators of the relationship between customer satisfaction and loyalty—an empirical analysis", Psychology \& Marketing, Vol. 18 No. 1, pp. 43-66.

Homburg, C., Jozić, D. and Kuehnl, C. (2017), “Customer experience management: toward implementing an evolving marketing concept", Journal of the Academy of Marketing Science, Vol. 45 No. 3, pp. 377-401.

Huang, Y.-A., Lin, C. and Phau, I. (2015), "Idol attachment and human brand loyalty", European Journal of Marketing, Vol. 49 No. 7/8, pp. 1234-1255.

Jacoby, J. (1971), “A model of multi-brand loyalty”, Journal of Advertising Research, Vol. 11 No. 3, pp. 25-31.

Keller, K. L. (1993), “Conceptualizing, measuring, and managing customer based brand equity”, Journal of Marketing, Vol. 57 No.1, pp.1-22.

Kumar, V., Dalla Pozza, I. and Ganesh, J. (2013). Revisiting the satisfaction-loyalty relationship: empirical generalizations and directions for future research. Journal of Retailing, Vol. 89 No. 3, pp. 246-262. 
Leech, N.L. and Onwuegbuzie, A.J. (2009), “A typology of mixed methods research designs", Quality \& Quantity, Vol. 43 No. 2, pp. 265-275.

Leenheer, J., van Heerde, H.J., Bijmolt, T.H.A. and Smidts, A. (2007), "Do loyalty programs really enhance behavioral loyalty? An empirical analysis accounting for self-selecting members", International Journal of Research in Marketing, Vol. 24 No. 1, pp. 31-47.

Lincoln, Y.S. and Guba, E.G. (1985), Naturalistic Inquiry, Sage Publications, Beverly Hills, CA.

Loehlin, J.C. (1998), Latent Variable Models: An Introduction to Factor, Path, and Structural Analysis, Mahwah, NJ: Lawrence Erlbaum Associates.

Maier, E., Wilken, R. Schneider, H. and Kelemci Schneider, G. (2012), "In the mood to buy? Understanding the interplay of mood regulation and congruence in an international context", Marketing Letters, Vol. 23 No. 4, pp. 1005-1018.

Marshall, D. (2005), “Food as ritual, routine or convention”, Consumption, Markets and Culture, Vol. 8 No. 1, pp. 69-85.

Mason, J. (2006), "Mixing methods in a qualitatively driven way", Qualitative Research, Vol. 6 No. 1, pp. 9-25.

Matzler, K., Grabner-Kräuter, S., and Bidmon, S. (2008), "Risk aversion and brand loyalty: the mediating role of brand trust and brand affect", Journal of Product \& Brand Management, Vol. 17 No. 3, pp. 154-162.

McDonald, H., (2011), "Understanding the antecedents to public interest and engagement with heritage", European Journal of Marketing, Vol. 45 No. 5, pp. 780-804.

McKercher, B., Denizci-Guillet, B. and Ng, E. (2012), "Rethinking loyalty”, Annals of Tourism Research, Vol. 39 No. 2, pp. 708-734.

McMullan, R. and Gilmore, A. (2008), "Customer loyalty: an empirical study”, European Journal of Marketing, Vol. 42 No. 9/10, pp. 1084-1094. 
Menon, S. and Kahn, B.E. (1995), "The impact of context on variety seeking in product choices", Journal of Consumer Research, Vol. 22 No. 3, pp. 285-295.

Miles, M.B. and Huberman, A.M. (1994), Qualitative Data Analysis, Thousand Oaks, CA: Sage.

Mitchell, V.-W. (1999), “Consumer perceived risk: conceptualizations and models”, European Journal of Marketing, Vol. 33 No. 1/2, pp. 163-195.

Mitchell, V.-W. and Boustani, P. (1993), "Market development using new products and new customers: a role for perceived risk", European Journal of Marketing, Vol. 27 No. 2, pp. 1732.

Moore, E.S., Wilkie, W.L. and Lutz, R.J. (2002), "Passing the torch: intergenerational influences as a source of brand equity", Journal of Marketing, Vol. 66 No. 2, pp. 17-37.

Närvänen, E. and Goulding, C. (2016), "Sociocultural brand revitalization: the role of consumer collectives in bringing brands back to life", European Journal of Marketing, Vol. 50 No. 7/8, pp .1521-1546.

Nielsen (2014), "The state of private label around the world", available at: http://www.nielsen.com/content/dam/nielsenglobal/kr/docs/globalreport/2014/Nielsenpercent20Globalpercent20Privatepercent20Labelpercent20Reportpercen t20Novemberpercent202014.pdf (accessed 12 April 2017).

Ngobo, P.V. (2004), “Motivations of customers' cross-buying intentions", European Journal of Marketing, Vol. 38 No. 9/10, pp. 1129-1157.

Ngobo, P.V. (2017), “The trajectory of customer loyalty: an empirical test of Dick and Basu's loyalty framework", Journal of the Academy of Marketing Science, Vol. 45 No. 2, pp. 229250.

Noble, S.M., Haytko, D.L., and Phillips, J. (2009), "What drives college-age Generation Y consumers?", Journal of Business Research, Vol. 62 No. 6, pp. 617-628. 
Oliver, R.L. (1999), “Whence consumer loyalty”, Journal of Marketing, Vol. 63 No. 4, pp. 3344.

Ouwersloot, H. and Odekerken-Schröder, G. (2008), "Who's who in brand communities - and why?”, European Journal of Marketing, Vol. 42 No. 5/6, pp. 571-585.

Parker, P.M. and Tavassoli, N.T. (2000), "Homeostasis and consumer behavior across cultures" International Journal of Research in Marketing, Vol. 17 No. 1, pp. 33-53.

Paulssen, M., Roulet, R., and Wilke, S. (2014), "Risk as moderator of the trust-loyalty relationship”, European Journal of Marketing, Vol. 48 No. 5/6, pp. 964-981.

Pimentel, R.W. and Reynolds, K.E. (2004), "A model for consumer devotion: affective commitment with proactive sustaining behaviors", Academy of Marketing Science Review, Vol. 5 No. 5, pp. 1-45.

Quoquab, F., Yasin, N.M. and Dardak, R.A. (2014), “A qualitative inquiry of multi-brand loyalty: some propositions and implications for mobile phone service providers", Asia Pacific Journal of Marketing and Logistics, Vol. 26 No. 2, pp. 250-271.

Raggio, R.D., Walz, A.M., Godbole, M.B. and Garretson Folse, J.A. (2014), “Gratitude in relationship marketing: theoretical development and directions for future research", European Journal of Marketing, Vol. 48 No. 1/2, pp. 2-44.

Ramaswami, S.N. and Arunachalam, S. (2016), "Divided attitudinal loyalty and customer value: role of dealers in an indirect channel”, Journal of the Academy of Marketing Science, Vol. 44 No. 6 , pp. $770-790$.

Reinartz, W., Thomas, J.S. and Kumar, V. (2005), "Balancing acquisition and retention resources to maximize customer profitability", Journal of Marketing, Vol. 69 No. 1, pp. 6379. 
Roy, S.K., Lassar, W.M. and Butaney, G.T. (2014), "The mediating impact of stickiness and loyalty on word-of-mouth promotion of retail websites: a consumer perspective", European Journal of Marketing, Vol. 48 No. 9/10, pp. 1828-1849.

Rundle-Thiele, S. and Bennett, R. (2001), “A brand for all seasons? A discussion of brand loyalty approaches and their applicability for different markets", Journal of Product \& Brand Management, Vol. 10 No. 1, pp. 25-37.

Saunders, B., Sim, J., Kingstone, T., Baker, S., Waterfield, J., Bartlam, B., Burroughs, H. and Jinks, C. (2018), "Saturation in qualitative research: exploring its conceptualization and operationalization”, Quality \& Quantity, Vol. 52 No. 4, pp. 1893-1907.

Shum, P., Bove, L. and Auh, S. (2008), "Employees' affective commitment to change: the key to successful CRM implementation”, European Journal of Marketing, Vol. 42 No. 11/12, pp. 1346-1371.

Sirgy, M.J., Lee, D.-J., Johar, J.S. and Tidwell, J. (2008), “Effect of self-congruity with sponsorship on brand loyalty", Journal of Business Research, Vol. 61 No. 10, pp. 1091-1097. Smith, S.M., Roster, C.A., Golden, L.L. and Albaum, G.S. (2016), “A multi-group analysis of online survey respondent data quality: comparing a regular USA consumer panel to MTurk samples", Journal of Business Research, Vol. 69 No. 8, pp. 3139-3148.

Spiggle, S. (1994), “Analysis and interpretation of qualitative data in consumer research”, Journal of Consumer Research, Vol. 21 No. 3, pp. 491-503.

Ulver, S. and Ostberg, J. (2014), "Moving up, down or sideways? Exploring consumer experience of identity and status incongruence", European Journal of Marketing, Vol. 48 No. 5/6, pp. 833-853.

Uncles, M.D., Dowling, G. R., and Hammond, K. (2003), “Customer loyalty and customer loyalty programs”, Journal of Consumer Marketing, Vol. 20 No. 4, pp. 294-316. 
Uncles, M.D. and Kwok, S. (2013), "Designing research with in-built differentiated replication", Journal of Business Research, Vol. 66 No. 9, pp. 1398-1405.

Uncles, M.D., Wang, C. and Kwok, S. (2010). A temporal analysis of behavioural brand loyalty among urban Chinese consumers", Journal of Marketing Management, Vol. 26 No. 9-10, pp. 921-942.

Verhage, B.J., Yavas, U. and Green, R.T. (1990), “Perceived risk: a cross-cultural phenomenon?", International Journal of Research in Marketing, Vol. 7 No. 4, pp. 297-303.

Walsh, G., Evanschitzky, H. and Wunderlich, M. (2008), "Identification and analysis of moderator variables: Investigating the customer satisfaction-loyalty link", European Journal of Marketing, Vol. 42 No. 9/10, pp. 977-1004.

Walsh, G., Hennig-Thurau, T. and Mitchell, V.-W. (2007), "Consumer confusion proneness: scale development, validation, and application", Journal of Marketing Management, Vol. 23 No. 7-8, pp. 697-721.

Watson, G., Beck, J., Henderson, C. and Palmatier, R.W. (2015), “Building, measuring, and profiting from customer loyalty", Journal of the Academy of Marketing Science, Vol. 43 No. 6, pp. $790-825$.

Woratschek, H. and Horbel, C. (2006), "Are variety-seekers bad customers? An analysis of the role of recommendations in the service profit chain", Journal of Relationship Marketing, Vol. 4 No. 3/4, pp. 43-58.

World Bank (2017), “Gross national income per capita 2017, Atlas method and PPP”, available at: http://databank.worldbank.org/data/download/GNIPC.pdf (accessed October 8, 2018).

Xiong, L., King, C. and Hu, C. (2014), "Where is the love? Investigating multiple membership and hotel customer loyalty", International Journal of Contemporary Hospitality Management, Vol. 26 No. 4, pp. 572-592. 
Yi, Y. and Jeon, H. (2003), "Effects of loyalty programs on value perception, program loyalty, and brand loyalty", Journal of the Academy of Marketing Science, Vol. 31 No. 3, pp. 229240.

Yoon, K. and Tran, T.V. (2011), "Revisiting the relationship between consumer loyalty and price sensitivity: the moderating role of deal-proneness", Journal of Marketing Theory and Practice, Vol. 19 No. 3, pp. 293-306.

Zarantonello, L. and Schmitt, B.H. (2010), "Using the brand experience scale to profile consumers and predict consumer behaviour", Journal of Brand Management, Vol. 17 No. 7 , pp. 532-540. 
Table 1. Means and standard deviations of clustering variables

\begin{tabular}{|c|c|c|c|c|c|c|c|c|}
\hline \multirow{2}{*}{$\begin{array}{l}\text { Cluster } \\
\text { no. }\end{array}$} & \multirow[t]{2}{*}{$\mathbf{N}(\%)$} & \multicolumn{4}{|c|}{ Means (SD) } & \multirow[b]{2}{*}{ Biased } & \multirow[b]{2}{*}{ CB-MBL } & \multirow[b]{2}{*}{ PS-MBL } \\
\hline & & $\begin{array}{c}\text { Mood } \\
\text { congruence }\end{array}$ & $\begin{array}{c}\text { Identity } \\
\text { enhancement }\end{array}$ & $\begin{array}{l}\text { Unavailability } \\
\text { risk reduction }\end{array}$ & $\begin{array}{c}\text { Market } \\
\text { competition }\end{array}$ & & & \\
\hline 1 & $48(19.35 \%)$ & $4.08(1.18)$ & $2.01(.83)$ & $4.54(1.23)$ & 4.69 (1.17) & $4.90(1.26)$ & $4.76(1.28)$ & $3.76(1.57)$ \\
\hline 2 & $127(51.21 \%)$ & $4.95(.98)$ & $4.57(.97)$ & $4.42(1.05)$ & $4.69(1.03)$ & $5.08(1.05)$ & $5.03(1.08)$ & $4.29(1.25)$ \\
\hline 3 & $73(29.44 \%)$ & $2.14(.95)$ & $1.96(.92)$ & $2.95(1.38)$ & $2.47(1.08)$ & $4.74(1.33)$ & $4.47(1.77)$ & $3.40(1.61)$ \\
\hline Total & $248(100 \%)$ & 3.95 (1.58) & 3.31 (1.59) & 4.01 (1.37) & $4.04(1.47)$ & 4.95 (1.18) & 4.82 (1.37) & $3.93(1.47)$ \\
\hline
\end{tabular}

$\overline{\mathrm{CB}-\mathrm{MBL}}=$ Complements-based multi-brand loyalty; PS-MBL $=$ perfect substitutes multi-brand loyalty. 
Table 2. Juxtaposition of MBL facets with extant literature on SBL

\begin{tabular}{|c|c|c|}
\hline Facet & Extant literature in a SBL context & $\begin{array}{c}\text { Meaning and relevance in a MBL } \\
\text { context }\end{array}$ \\
\hline Risk & $\begin{array}{l}\text { - SBL is perceived as a risk-reduction } \\
\text { strategy (Matzler et al., 2008; } \\
\text { Mitchell and Boustani, 1993; } \\
\text { Verhage et al., 1990). } \\
\text { - Risk-averse consumers show higher } \\
\text { levels of attitudinal and behavioural } \\
\text { loyalty to a specific brand (Gounaris } \\
\text { and Stathakopoulus, 2004). }\end{array}$ & $\begin{array}{l}\text { - SBL is perceived as a potentially risky } \\
\text { strategy because the target brand may not } \\
\text { be available at the point-of-purchase. } \\
\text { - MBL serves as a strategy to benefit from } \\
\text { the advantages of loyalty heuristics } \\
\text { (reduced cognitive effort, trust) while } \\
\text { reducing the inherent product- } \\
\text { unavailability risk of SBL. }\end{array}$ \\
\hline Competition & $\begin{array}{l}\text { Micro-perspective: Firms employ } \\
\text { promotions such as feature } \\
\text { advertising, end-of-aisle product } \\
\text { displays and discounts to lure } \\
\text { customers away from the competitor } \\
\text { brand (Empen et al., 2015; Ngobo, } \\
\text { 2017). }\end{array}$ & $\begin{array}{l}\text { - Macro-perspective: Consumers take } \\
\text { advantage of intense competition } \\
\text { between firms and a plethora of market } \\
\text { offers by expanding their loyalty set } \\
\text { beyond just one single brand. }\end{array}$ \\
\hline Affect & $\begin{array}{l}\text { - SBL emphasizes emotional } \\
\text { attachment and positive emotions } \\
\text { towards the brand as antecedents for } \\
\text { brand loyalty (Carroll and Ahuvia, } \\
\text { 2006; Chaudhuri and Holbrook, } \\
\text { 2001; Batra et al., 2012). }\end{array}$ & $\begin{array}{l}\text { - Emotional attachment does not guarantee } \\
\text { unconditional loyalty because consumers } \\
\text { in MBL frequently use different brands } \\
\text { strategically to adjust to different mood } \\
\text { states. }\end{array}$ \\
\hline Identity & $\begin{array}{l}\text { - SBL focuses on self-congruity with } \\
\text { the brand (He et al., 2012; Sirgy et } \\
\text { al., 2008). High congruence between } \\
\text { the self and the brand leads to SBL. } \\
\text { - Consumers use single brands to } \\
\text { execute individual identity projects, } \\
\text { such as emancipation from parents } \\
\text { (Fournier and Yao, 1997) }\end{array}$ & $\begin{array}{l}\text { - Identities can be diffuse, divided, or } \\
\text { dissolved. Consumers may hold different } \\
\text { and potentially contradicting identities } \\
\text { and use competing brands to configure } \\
\text { an ambivalent personality. }\end{array}$ \\
\hline
\end{tabular}


Figure 1. Overview of previous literature on brand loyalty and research gap

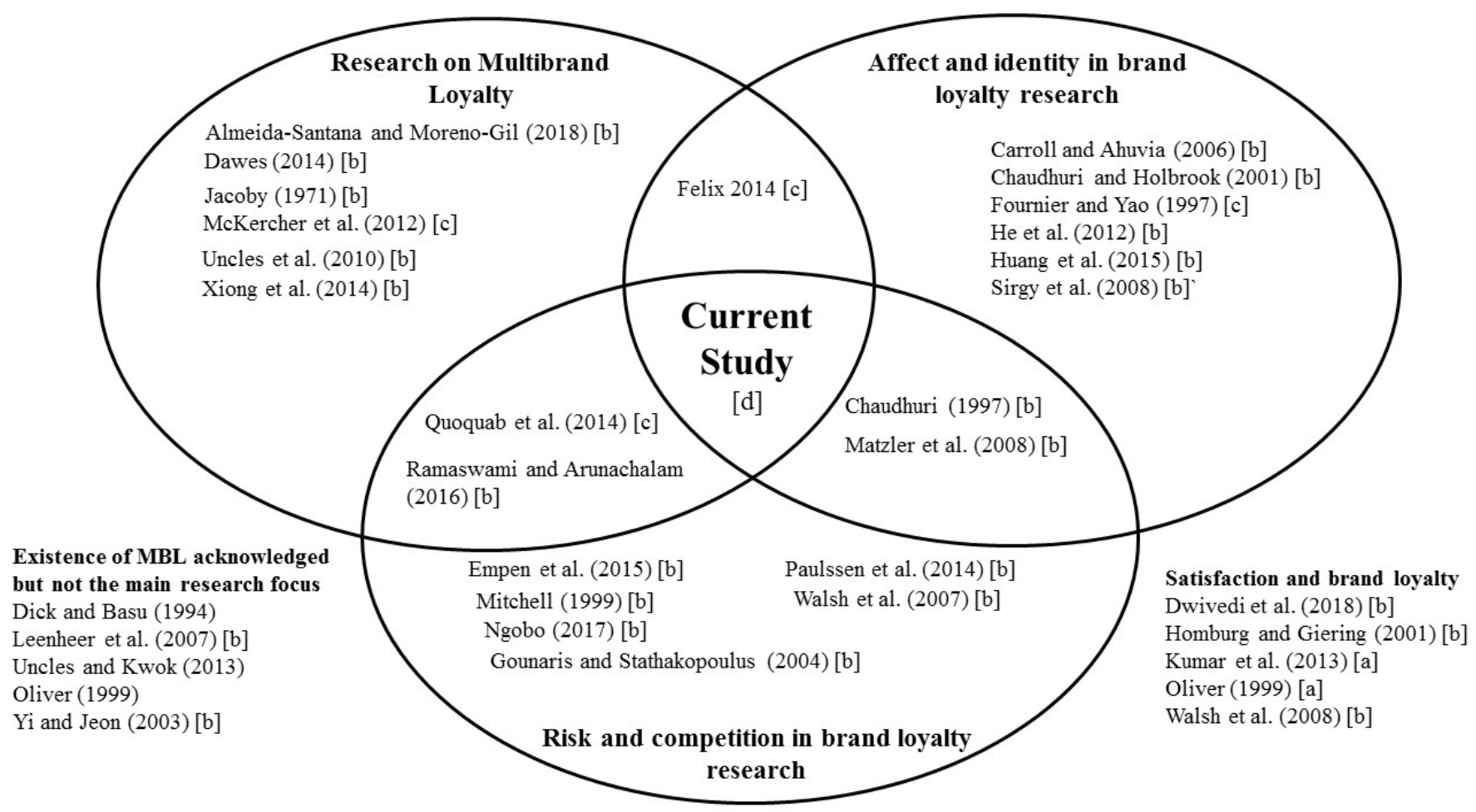

Note: [a] Conceptual; [b] Quantitative/theory testing; [c] Interpretative/theory building; [d] Mixed method 
Figure 2. Types and facets of multi-brand loyalty

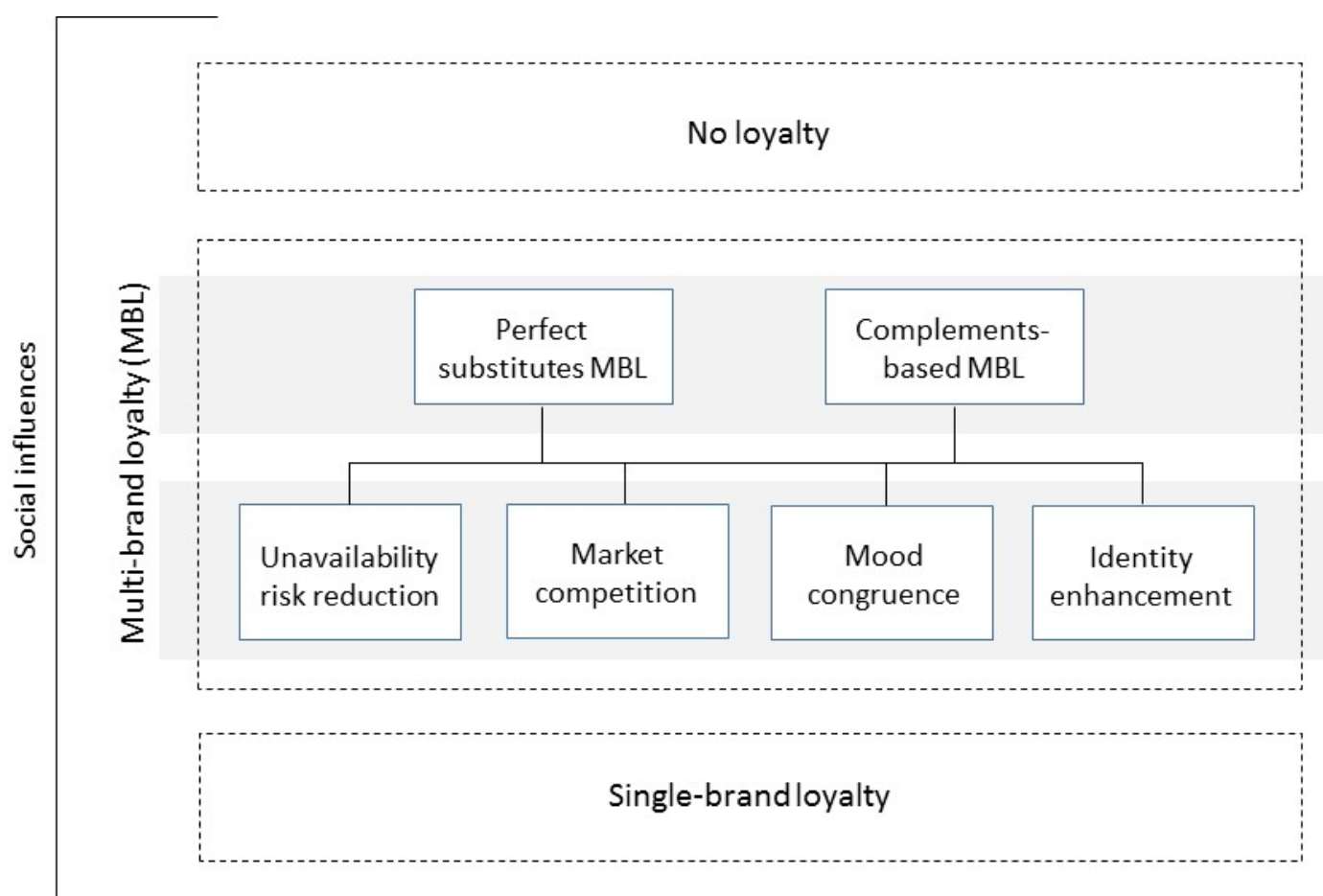

Types of MBL

Facets of MBL 
Figure 3. Family influence and brand loyalty

Family-endorsed brand (initial influence)

Process

Outcome

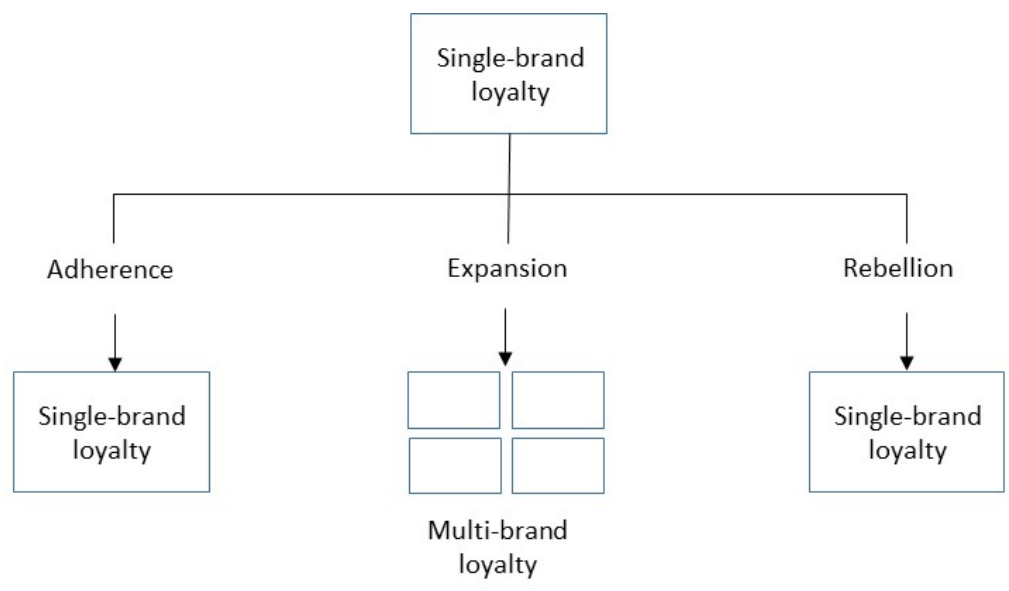


Appendix 1:

Semi-structured (first stage) and unstructured (second and third stage) interviews

\begin{tabular}{|c|c|c|c|c|c|c|c|}
\hline Research stage & Type* & $\begin{array}{c}\text { Name } \\
\text { (pseudonym) }\end{array}$ & Gender & Age & Marital Status & $\begin{array}{c}\text { Interview } \\
\text { Length } \\
\text { (min) }\end{array}$ & $\begin{array}{c}\text { Interview } \\
\text { Length } \\
\text { Mean (min) }\end{array}$ \\
\hline & $\mathrm{N}$ & Marc & Male & 32 & Single & 28 & \\
\hline & $\mathrm{N}$ & Eric & Male & 51 & Married & 37 & \\
\hline & $\mathrm{N}$ & Phillip & Male & 30 & Single & 48 & \\
\hline & $\mathrm{N}$ & Emilie & Female & 26 & Single & 31 & \\
\hline & $\mathrm{N}$ & Jasmine & Female & 47 & Married & 36 & \\
\hline & $\mathrm{N}$ & Andrew & Male & 24 & Single & 36 & \\
\hline & $\mathrm{N}$ & Ana & Female & 25 & Single & 37 & \\
\hline & $\mathrm{N}$ & Caroline & Female & 29 & Single & 25 & \\
\hline Panel A & $\mathrm{N}$ & Sara & Female & 50 & Married & 31 & \\
\hline (First stage) & $\mathrm{N}$ & Jennifer & Female & 24 & Single & 31 & \\
\hline Semi-structured & $\mathrm{N}$ & Martin & Male & 30 & In a relationship & 32 & 33.8 \\
\hline \multirow[t]{11}{*}{ Interviews } & $\mathrm{N}$ & Patricia & Female & 27 & Single & 35 & \\
\hline & $\mathrm{N}$ & Christopher & Male & 35 & Single & 37 & \\
\hline & $\mathrm{N}$ & Daniel & Male & 32 & Married & 37 & \\
\hline & $\mathrm{N}$ & Robert & Male & 24 & Single & 37 & \\
\hline & $\mathrm{N}$ & Barbara & Female & 48 & Married & 35 & \\
\hline & $\mathrm{N}$ & Paul & Male & 49 & In a relationship & 25 & \\
\hline & $\mathrm{N}$ & Kevin & Male & 34 & Single & 32 & \\
\hline & $\mathrm{N}$ & Linda & Female & 38 & Single & 34 & \\
\hline & $\mathrm{N}$ & Laura & Female & 23 & Single & 32 & \\
\hline & $\mathrm{C}$ & Eric & Male & 51 & Married & 59 & \\
\hline & $\mathrm{C}$ & Philip & Male & 30 & Single & 51 & \\
\hline Panel B & $\mathrm{C}$ & Christopher & Male & 35 & Single & 60 & \\
\hline (Second stage) & $\mathrm{C}$ & Daniel & Male & 32 & Married & 60 & \\
\hline Unstructured & $\mathrm{N}$ & Peter & Male & 26 & Single & 55 & 48 \\
\hline \multirow[t]{4}{*}{ Interviews } & $\mathrm{N}$ & Emma & Female & 36 & Married & 40 & \\
\hline & $\mathrm{N}$ & Olivia & Female & 43 & In a relationship & 59 & \\
\hline & $\mathrm{N}$ & Sophia & Female & 22 & Single & 40 & \\
\hline & $\mathrm{N}$ & Claudia & Female & 37 & Single & 59 & \\
\hline Panel C & $\mathrm{N}$ & David & Male & 32 & Married & 70 & \\
\hline (Third stage) & $\mathrm{N}$ & Mayra & Female & 26 & Married & 60 & \\
\hline Unstructured & $\mathrm{N}$ & Nydia & Female & 27 & Single & 61 & 64.3 \\
\hline \multirow[t]{2}{*}{ Interviews } & $\mathrm{N}$ & Melanie & Female & 36 & In a relationship & 75 & \\
\hline & $\mathrm{N}$ & Xavier & Male & 31 & Married & 61 & \\
\hline
\end{tabular}

${ }^{*} \mathrm{C}=$ continuation from the first stage (semi-structured interviews); $\mathrm{N}=$ new informant. 
Appendix 2: Aggregated buying behaviours based on informants' self-reports

\begin{tabular}{|c|c|c|c|c|}
\hline $\begin{array}{l}\text { Product } \\
\text { categories }\end{array}$ & $\begin{array}{c}\text { No loyalty } \\
\text { I don't care about } \\
\text { the brand, I } \\
\text { randomly buy } \\
\text { different brands } \\
\end{array}$ & $\begin{array}{l}\text { Multi-brand loyal } \\
\text { From a set of } \\
\text { competing brands, I } \\
\text { buy two or more } \\
\text { brands regularly } \\
\end{array}$ & $\begin{array}{l}\text { Single-brand loyal } \\
\text { From a set of } \\
\text { competing brands, I } \\
\text { regularly buy only one } \\
\text { brand } \\
\end{array}$ & $\begin{array}{l}\text { No purchase } \\
\text { I never buy } \\
\text { products from } \\
\text { this category }\end{array}$ \\
\hline \multicolumn{5}{|c|}{ Food products: non-alcoholic beverages } \\
\hline Bottled water & 2 & 3 & 5 & 16 \\
\hline Ice tea & 2 & 1 & 3 & 20 \\
\hline Juice & 7 & 5 & 4 & 10 \\
\hline Soft drinks & 1 & 3 & 5 & 17 \\
\hline Tea & 5 & 5 & 5 & 11 \\
\hline Coffee & 1 & 5 & 12 & 8 \\
\hline \multicolumn{5}{|c|}{ Food products: alcoholic beverages and cigarettes } \\
\hline Wine & 12 & 4 & 3 & 7 \\
\hline Beer & 3 & 11 & 4 & 8 \\
\hline Cigarettes & 1 & 1 & 1 & 23 \\
\hline \multicolumn{5}{|c|}{ Food products: dairy } \\
\hline Milk & 8 & 6 & 6 & 6 \\
\hline Cheese & 13 & 4 & 5 & 4 \\
\hline Yogurt & 5 & 6 & 5 & 10 \\
\hline \multicolumn{5}{|c|}{ Food products: snacks } \\
\hline Chocolate & 6 & 9 & 4 & 7 \\
\hline Sweets & 10 & 2 & 2 & 12 \\
\hline Chips & 4 & 5 & 5 & 12 \\
\hline \multicolumn{5}{|c|}{ Non-food products: personal care and cleaning } \\
\hline Toothpaste & 12 & 3 & 10 & 1 \\
\hline Toothbrushes & 17 & 0 & 8 & 1 \\
\hline Shampoos & 6 & 6 & 12 & 2 \\
\hline Shower gel & 12 & 8 & 4 & 2 \\
\hline $\begin{array}{l}\text { Body cream, } \\
\text { body lotion }\end{array}$ & 13 & 4 & 7 & 2 \\
\hline Soap & 20 & 0 & 3 & 3 \\
\hline Deodorant & 5 & 4 & 16 & 1 \\
\hline Shaving cream & 4 & 3 & 5 & 14 \\
\hline Sun protection & 13 & 1 & 7 & 5 \\
\hline Razors & 7 & 2 & 12 & 5 \\
\hline $\begin{array}{l}\text { Laundry } \\
\text { products }\end{array}$ & 13 & 2 & 6 & 5 \\
\hline \multicolumn{5}{|c|}{ Non-food products: cosmetics and beauty products } \\
\hline Make up & 4 & 6 & 3 & 13 \\
\hline Hair styling & 6 & 4 & 4 & 12 \\
\hline Colognes & 6 & 7 & 10 & 3 \\
\hline Hair colour & 3 & 0 & 0 & 23 \\
\hline \multicolumn{5}{|c|}{ Non-food products: consumer durables } \\
\hline Phones & 7 & 4 & 15 & 0 \\
\hline Computers & 11 & 4 & 10 & 1 \\
\hline $\begin{array}{l}\text { Business } \\
\text { clothes }\end{array}$ & 15 & 5 & 6 & 0 \\
\hline Sport wear & 17 & 5 & 3 & 1 \\
\hline Shoes & 22 & 3 & 1 & 0 \\
\hline Sports shoes & 17 & 7 & 2 & 0 \\
\hline Watches & 13 & 6 & 2 & 5 \\
\hline Total & 323 & 154 & 215 & 270 \\
\hline
\end{tabular}




\section{Appendix 3: Exemplary coding results of the thematic analysis}

\begin{tabular}{|c|c|c|c|c|}
\hline & $\begin{array}{c}\text { Zero-order } \\
\text { categories }\end{array}$ & $\begin{array}{c}\text { First-order } \\
\text { categories }\end{array}$ & $\begin{array}{c}\text { Second order } \\
\text { categories }\end{array}$ & Themes \\
\hline $\begin{array}{l}1 . \\
2 . \\
3 . \\
4 . \\
5 . \\
6 . \\
7 . \\
8 . \\
9 . \\
10 .\end{array}$ & $\begin{array}{l}\text { Different tastes } \\
\text { Consumption according to occasions } \\
\text { Different functionalities } \\
\text { Different brand positioning } \\
\text { Authenticity and uniqueness of each brand } \\
\text { Similar brands quality } \\
\text { Convenience } \\
\text { Similar brand value } \\
\text { Preference of few brands among others } \\
\text { Similar functionality of few brands }\end{array}$ & $\begin{array}{l}\text { - Preference within } \\
\text { the loyalty set } \\
\text { - Substitute brands }\end{array}$ & $\begin{array}{l}\text { - Perfect substitutes } \\
\quad \text { MBL }\end{array}$ & MBL Types \\
\hline $\begin{array}{l}11 . \\
12 . \\
13 . \\
14 .\end{array}$ & $\begin{array}{l}\text { Purchase according to mood } \\
\text { Consumption according to mood } \\
\text { Different mood states according to the season } \\
\text { Consumption to adapt to current feeling } \\
\text { (eagerness, happiness, sadness) }\end{array}$ & $\begin{array}{l}\text { - Different moods } \\
\text { - Adaptation to } \\
\text { mood state }\end{array}$ & - Mood congruence & \\
\hline $\begin{array}{l}15 . \\
16 . \\
17 . \\
18 . \\
19 . \\
20 .\end{array}$ & $\begin{array}{l}\text { Similar brand value } \\
\text { Similar price for similar brands } \\
\text { High competition } \\
\text { Trust conveyed through brand loyalty } \\
\text { Feeling of security offered by brand loyalty } \\
\text { Ease of decision making with limited number of } \\
\text { choices } \\
\text { Choice overload in the market }\end{array}$ & $\begin{array}{l}\text { - Pressure from } \\
\text { competition } \\
\text { - Pressure reduction }\end{array}$ & - Market competition & MBL facets \\
\hline $\begin{array}{l}22 . \\
23 . \\
24 . \\
25 .\end{array}$ & $\begin{array}{l}\text { Proximity to stores } \\
\text { Risk avoidance } \\
\text { Lack of time } \\
\text { Energy and effort needed when seeking new } \\
\quad \text { options } \\
\text { Brand availability in stores }\end{array}$ & $\begin{array}{l}\text { - Risk aversion } \\
\text { - Unavailability of } \\
\text { preferred brand }\end{array}$ & $\begin{array}{l}\text { - Unavailability risk } \\
\text { reduction }\end{array}$ & \\
\hline $\begin{array}{l}28 . \\
29 .\end{array}$ & $\begin{array}{l}\text { Loyalty as a personal characteristics/as a } \\
\text { personality trait } \\
\text { Representation of different personalities } \\
\text { Having different roles in society }\end{array}$ & $\begin{array}{l}\text { - } \text { Multi- } \\
\text { representation in } \\
\text { society } \\
\text { - Different } \\
\text { personalities }\end{array}$ & $\begin{array}{l}\text { - Identity } \\
\text { enhancement }\end{array}$ & \\
\hline $\begin{array}{l}30 . \\
31 . \\
32 . \\
33 .\end{array}$ & $\begin{array}{l}\text { Recommendations from family } \\
\text { Attachment to family } \\
\text { Adaptability to family preferences } \\
\text { Loyalty transition from family }\end{array}$ & $\begin{array}{l}\text { - Adaptation to } \\
\text { family tradition } \\
\text { - Adaptation to } \\
\text { family preferences }\end{array}$ & $\begin{array}{l}\text { - Adherence toward } \\
\text { SBL }\end{array}$ & \\
\hline $\begin{array}{l}34 . \\
35 . \\
36 .\end{array}$ & $\begin{array}{l}\text { Internalization of own preferences } \\
\text { Alignment with friends preferred brands } \\
\text { Single to multiple loyal over time (from parents } \\
\text { influence to partner influence) } \\
\text { Adaptability to family preferences }\end{array}$ & $\begin{array}{l}\text { - Brand set } \\
\text { expansion } \\
\text { - MBL as a process }\end{array}$ & - Expansion to MBL & $\begin{array}{l}\text { Family } \\
\text { influence }\end{array}$ \\
\hline $\begin{array}{l}38 . \\
39 . \\
40 .\end{array}$ & $\begin{array}{l}\text { Pressure from society } \\
\text { Need of freedom in brand choice } \\
\text { Family tradition breakage }\end{array}$ & $\begin{array}{l}\text { - SBL toward a } \\
\text { different brand }\end{array}$ & $\begin{array}{l}\text { - Rebellion toward } \\
\text { SBL }\end{array}$ & \\
\hline
\end{tabular}




\begin{tabular}{|c|c|c|c|c|}
\hline Constructs and items & $\begin{array}{c}\text { Means } \\
(\mathbf{M})\end{array}$ & $\begin{array}{c}\text { Standard } \\
\text { deviation } \\
\text { (SD) }\end{array}$ & $\begin{array}{c}\text { Factor } \\
\text { loadings } \\
\text { from EFA }\end{array}$ & $\begin{array}{c}\text { Factor } \\
\text { loadings } \\
\text { from CFA }\end{array}$ \\
\hline
\end{tabular}

\begin{tabular}{|c|c|c|c|c|}
\hline \multicolumn{5}{|l|}{ Mood Congruence $(\alpha=0.89, \mathrm{AVE}=0.67, \mathrm{CR}=0.89)$} \\
\hline Mood $1:$ I buy different brands in this category based on my & 3.82 & 1.908 & .762 & .820 \\
\hline or another brand from this category & 4.05 & 1.846 & .757 & .797 \\
\hline $\begin{array}{l}\text { Mood } 3 \text { : Sometimes, I feel a certain way and prefer one brand } \\
\text { among my preferred brands in this category, and sometimes } \\
\text { my feelings change, and I buy another brand. }\end{array}$ & 3.97 & 1.831 & .826 & .841 \\
\hline $\begin{array}{l}\text { Mood } 4 \text { : Among my preferred brands in this category, I buy } \\
\text { the one that fit best with my mood at that time. }\end{array}$ & 3.95 & 1.817 & .820 & .820 \\
\hline \multicolumn{5}{|l|}{ Identity Enhancement $(\alpha=0.87$, AVE $=0.60, C R=0.86)$} \\
\hline $\begin{array}{l}\text { Identity 1: The different brands I buy in this category represent } \\
\text { my different personalities. }\end{array}$ & 3.71 & 1.807 & .675 & .785 \\
\hline $\begin{array}{l}\text { Identity 2: To represent the different facets of my personality, I } \\
\text { buy different brands from this category. }\end{array}$ & 3.34 & 1.872 & .812 & .890 \\
\hline $\begin{array}{l}\text { Identity } 3 \text { : I use different brands from this category to change } \\
\text { the way other people perceive me. }\end{array}$ & 2.91 & 1.893 & .811 & .699 \\
\hline $\begin{array}{l}\text { Identity } 4 \text { : I buy several brands from this category, and then in } \\
\text { a specific occasion I use the one that represents best the image } \\
\text { I want to show to other people. }\end{array}$ & 3.26 & 1.944 & .830 & .728 \\
\hline \multicolumn{5}{|l|}{ Unavailability Risk Reduction $(\alpha=0.80, A V E=0.61, C R=0.82)$} \\
\hline $\begin{array}{l}\text { Unavailability } 1 \text { : I buy different brands from this category } \\
\text { because it reduces the risk of not finding my favourite brand } \\
\text { during my shopping trip. }\end{array}$ & 3.38 & 1.791 & .649 & .578 \\
\hline $\begin{array}{l}\text { Unavailability 2: The brands I like in this category are very } \\
\text { similar, therefore I buy the one brand, which is available in the } \\
\text { store I shop. }\end{array}$ & 3.86 & 1.848 & .847 & .895 \\
\hline $\begin{array}{l}\text { Unavailability } 3 \text { : I don't see much differences between the } \\
\text { brands I like in this category, thus I buy the one that is } \\
\text { available }\end{array}$ & 3.77 & 1.856 & .871 & .837 \\
\hline \multicolumn{5}{|l|}{ Market competition $(\alpha=0.70, \mathrm{AVE}=0.45, \mathrm{CR}=0.71)$} \\
\hline $\begin{array}{l}\text { Competition 1: I buy several brands in this category because } \\
\text { there are so many brands available and I want to take } \\
\text { advantage of it. }\end{array}$ & 3.85 & 1.838 & .501 & .757 \\
\hline $\begin{array}{l}\text { Competition } 2 \text { : I buy several brands in this category because } \\
\text { there are so many brands available and I want to take } \\
\text { advantage of it. }\end{array}$ & 4.48 & 1.589 & .460 & .604 \\
\hline $\begin{array}{l}\text { Competition 3: I don't like every brand in this category, but I } \\
\text { buy several of them to have a bit of variety. }\end{array}$ & 3.84 & 1.749 & .446 & .639 \\
\hline \multicolumn{5}{|l|}{ Biased MBL $(\alpha=0.78$, AVE $=0.61$, CR $=0.81)$} \\
\hline $\begin{array}{l}\text { Biased 1: Out of the brands I buy in this category, there is one } \\
\text { that I like more than the others }\end{array}$ & 5.20 & 1.359 & .914 & .888 \\
\hline $\begin{array}{l}\text { Biased 2: Among the brands I prefer in this category, there is } \\
\text { one that I prefer over the others. }\end{array}$ & 5.02 & 1.465 & .914 & .911 \\
\hline $\begin{array}{l}\text { Biased 3: I sometimes buy different brands I like in this } \\
\text { category, but I always come back to my most preferred brand }\end{array}$ & 4.62 & 1.426 & 622 & .465 \\
\hline
\end{tabular}

Factor loadings are standardized factor loadings. $\mathrm{p}<.001$ for all factor loadings from CFA shown in the table. 
Appendix 5: Discriminant validity assessment

\begin{tabular}{|c|c|c|c|c|c|c|c|}
\hline & Mean & SD & 1 & 2 & 3 & 4 & 5 \\
\hline 1. Mood Congruence & & & .82 & & & & \\
\hline 2. Identity Enhancement & & & .67 & .77 & & & \\
\hline 3. Unavailability Risk Reduction & & & .42 & .27 & .78 & & \\
\hline 4. Market competition & & & .70 & .58 & .57 & .67 & \\
\hline 5 Biased MBL & & & .19 & .16 & -.07 & .19 & .78 \\
\hline
\end{tabular}

Bold numbers on the diagonal show the square root of AVE. Numbers on the off-diagonal represent the correlations between the constructs. 


\section{Appendix 6: Cluster validation}

\begin{tabular}{|c|c|c|c|c|c|}
\hline \multirow{2}{*}{$\begin{array}{l}\text { Cluster } \\
\text { no. }\end{array}$} & \multirow[t]{2}{*}{ N (per cent) } & \multicolumn{4}{|c|}{ Means (SD) } \\
\hline & & $\begin{array}{c}\text { Mood } \\
\text { congruence }\end{array}$ & $\begin{array}{c}\text { Identity } \\
\text { enhancement }\end{array}$ & $\begin{array}{l}\text { Unavailability } \\
\text { risk reduction }\end{array}$ & $\begin{array}{c}\text { Market } \\
\text { competition }\end{array}$ \\
\hline 1 & $29(22.83 \%)$ & $5.62(.74)$ & $5.27(.87)$ & $5.32(.81)$ & $5.64(.52)$ \\
\hline 2 & $58(45.67 \%)$ & $4.12(1.22)$ & $3.35(1.48)$ & $4.12(1.02)$ & $4.36(.89)$ \\
\hline 3 & $40(31.50 \%)$ & $2.41(.1 .20)$ & $1.84(.87)$ & $3.00(1.31)$ & $2.36(.92)$ \\
\hline Total & $127(100 \%)$ & $3.98(1.63)$ & $3.31(1.72)$ & $4.04(1.37)$ & $4.02(1.49)$ \\
\hline
\end{tabular}

Appendix 6b. Means and standard deviations of clustering variables - split sample 2

\begin{tabular}{lccccc}
\hline $\begin{array}{l}\text { Cluster } \\
\text { no. }\end{array}$ & N (per cent) & \multicolumn{4}{c}{ Means (SD) } \\
\cline { 3 - 6 } & & $\begin{array}{c}\text { Mood } \\
\text { congruence }\end{array}$ & $\begin{array}{c}\text { Identity } \\
\text { enhancement }\end{array}$ & $\begin{array}{c}\text { Unavailability } \\
\text { risk reduction }\end{array}$ & $\begin{array}{c}\text { Market } \\
\text { competition }\end{array}$ \\
\hline 1 & $13(10.74 \%)$ & $6.28(.59)$ & $5.42(.82)$ & $4.90(1.57)$ & $5.95(.49)$ \\
2 & $72(59.50 \%)$ & $4.40(.91)$ & $3.65(1.04)$ & $4.32(.95)$ & $4.49(.93)$ \\
3 & $36(29.75 \%)$ & $2.31(1.09)$ & $1.83(.83)$ & $3.00(1.50)$ & $2.47(1.08)$ \\
Total & $\mathbf{1 2 1 ( 1 0 0 \% )}$ & $\mathbf{3 . 9 8}(\mathbf{1 . 5 4 )}$ & $\mathbf{3 . 3 0}(\mathbf{1 . 4 5})$ & $\mathbf{3 . 9 9}(\mathbf{1 . 3 7})$ & $\mathbf{4 . 0 5}(\mathbf{1 . 4 6 )}$ \\
\hline
\end{tabular}




\title{
Authors
}

Ghizlane ARIFINE

Ph.D. Student, University of Fribourg, Bd. de Pérolles 90, 1700 Fribourg, Switzerland. e-mail: ghizlane.arifine@unifr.ch

Reto FELIX

Assistant Professor, University of Texas Rio Grande Valley, USA. e-mail: reto.felix@utrgv.edu

Olivier FURRER

Full Professor, University of Fribourg, Bd. de Pérolles 90, 1700 Fribourg, Switzerland. e-mail: olivier.furrer@unifr.c

\begin{abstract}
Purpose-Although multi-brand loyalty (MBL) in consumer markets has been identified in previous brand loyalty research, empirical studies have not yet explored the facets of its different types. This article seeks a deeper understanding of $\mathrm{MBL}$ by investigating its different types and facets.

Design/methodology/approach-This study uses a sequential, qualitatively-driven mixed method design consisting of in-depth interviews and supplementary survey research.

Findings-The findings of this study suggest that mood congruence, identity enhancement, unavailability risk reduction and market competition are the most important facets that explains the two types of MBL (complementarybased and product substitutes). Furthermore, the findings show that the family factor can motivate consumers to be multi-brand loyal by adding brands to an initially family-endorsed brand.

Research limitations/implications-This study advances the conceptual foundations of MBL and extends previous research on brand loyalty. Some of the findings may be limited to the economic and cultural context of relatively affluent countries with an abundance of market offers.

Practical implications-Marketing managers gain insights into how to manage brand loyalty as well as how to transition from MBL to single-brand loyalty.
\end{abstract}

Originality/value-The study generates novel insights into the facets of different types of MBL

\section{Citation proposal}

Ghizlane Arifine, Reto Felix, Olivier Furrer. 2019. «Multi-Brand Loyalty in Consumer Markets: A Qualitatively-Driven Mixed Methods Approach». Working Papers SES 501, Faculty of Economics and Social Sciences, University of Fribourg (Switzerland)

\section{Jel Classification}

M31

\section{Keywords}

Multi-brand loyalty, relationship marketing, decision-making heuristics, mixed method design, grounded theory, thematic analysis.

\section{Working Papers SES collection}

\section{Last published}

494 Huber M., Imhof D.: Machine Learning with Screens for Detecting Bid-Rigging Cartels; 2018

495 Hsu Y.-C., Huber M., Lee Y.-Y.: Direct and indirect effects of continuous treatments based on generalized propensity score weighting; 2018

496 Huber M., Solovyeva A.: Direct and indirect effects under sample selection and outcome attrition; 2018

497 Huber M., Solovyeva A.: On the sensitivity of wage gap decompositions; 2018

498 Isakov D., Pérignon C., Weisskopf J.-P.: What if dividends were tax-exempt? Evidence from a natural experiment; 2018

499 Denisova-Schmidt E., Huber M., Prytula Y.: The effects of anti-corruption videos on attitudes towards corruption in a Ukrainian online survey. 2019

500 Huber M.: A review of causal mediation analysis for assessing direct and indirect treatment effects. 2019

\section{Catalogue and download links}

http://www.unifr.ch/ses/wp

http://doc.rero.ch/collection/WORKING_PAPERS_SES

\section{Publisher}

Université de Fribourg, Suisse, Faculté des sciences économiques et sociales Universität Freiburg, Schweiz, Wirtschafts- und sozialwissenschaftliche Fakultät University of Fribourg, Switzerland, Faculty of Economics and Social Sciences
Bd de Pérolles 90, $\mathrm{CH}-1700$ Fribourg

Tél.: +41 (0) 263008200

decanat-ses@unifr.ch www.unifr.ch/ses 